\title{
Regulation of $\mathrm{GABA}_{\mathrm{A}}$ and Glutamate Receptor Expression, Synaptic Facilitation and Long-Term Potentiation in the Hippocampus of Prion Mutant Mice
}

\author{
Alejandra Rangel ${ }^{1,2}$, Noelia Madroñal ${ }^{3}$, Agnès Gruart i Massó ${ }^{3}$, Rosalina Gavín ${ }^{1,2}$, Franc Llorens ${ }^{1,2}$, Lauro \\ Sumoy $^{4}$, Juan María Torres ${ }^{5}$, José María Delgado-García ${ }^{3 *}$, José Antonio Del Río ${ }^{1,2 *}$ \\ 1 Molecular and Cellular Neurobiotechnology, Institute for Bioengineering of Catalonia, and Department of Cell Biology, University of Barcelona, Barcelona, Spain, \\ 2 Centro de Investigación Biomédica en Red de Enfermedades Neurodegenerativas (CIBERNED), Madrid, Spain, 3 Division de Neurociencias. Universidad Pablo de Olavide, \\ Sevilla, Spain, $\mathbf{4}$ Institute of Predictive and Personalized Medicine of Cancer, Badalona, Spain, $\mathbf{5}$ Centro de Investigación en Sanidad Animal (CISA), INIA, Valdeolmos, \\ Madrid, Spain
}

\begin{abstract}
Background: Prionopathies are characterized by spongiform brain degeneration, myoclonia, dementia, and periodic electroencephalographic (EEG) disturbances. The hallmark of prioniopathies is the presence of an abnormal conformational isoform $\left(P_{P^{s c}}\right)$ of the natural cellular prion protein $\left(\operatorname{PrP}^{\mathrm{C}}\right)$ encoded by the Prnp gene. Although several roles have been attributed to $\operatorname{PrP}^{\mathrm{C}}$, its putative functions in neuronal excitability are unknown. Although early studies of the behavior of Prnp knockout mice described minor changes, later studies report altered behavior. To date, most functional $\operatorname{Pr} P^{c}$ studies on synaptic plasticity have been performed in vitro. To our knowledge, only one electrophysiological study has been performed in vivo in anesthetized mice, by Curtis and coworkers. They reported no significant differences in paired-pulse facilitation or LTP in the CA1 region after Schaffer collateral/commissural pathway stimulation.
\end{abstract}

Methodology/Principal Findings: Here we explore the role of $\operatorname{PrP}^{\mathrm{C}}$ expression in neurotransmission and neural excitability using wild-type, Prnp -/- and PrPc -overexpressing mice (Tg20 strain). By correlating histopathology with electrophysiology in living behaving mice, we demonstrate that both Prnp -/- mice but, more relevantly Tg20 mice show increased susceptibility to KA, leading to significant cell death in the hippocampus. This finding correlates with enhanced synaptic facilitation in paired-pulse experiments and hippocampal LTP in living behaving mutant mice. Gene expression profiling using Illumina ${ }^{T M}$ microarrays and Ingenuity pathways analysis showed that 129 genes involved in canonical pathways such as Ubiquitination or Neurotransmission were co-regulated in Prnp $-/-$ and Tg20 mice. Lastly, RT-qPCR of neurotransmission-related genes indicated that subunits of $\mathrm{GABA}_{\mathrm{A}}$ and AMPA-kainate receptors are co-regulated in both Prnp $-/-$ and Tg20 mice.

Conclusions/Significance: Present results demonstrate that $\operatorname{PrP}^{c}$ is necessary for the proper homeostatic functioning of hippocampal circuits, because of its relationships with $G_{A B A}$ and AMPA-Kainate neurotransmission. New PrP ${ }^{C}$ functions have recently been described, which point to $\operatorname{PrP}^{c}$ as a target for putative therapies in Alzheimer's disease. However, our results indicate that a "gain of function" strategy in Alzheimer's disease, or a "loss of function" in prionopathies, may impair $\operatorname{PrP}^{c}$ function, with devastating effects. In conclusion, we believe that present data should be taken into account in the development of future therapies.

Citation: Rangel A, Madroñal N, Gruart i Massó A, Gavín R, Llorens F, et al. (2009) Regulation of GABA $A_{A}$ and Glutamate Receptor Expression, Synaptic Facilitation and Long-Term Potentiation in the Hippocampus of Prion Mutant Mice. PLoS ONE 4(10): e7592. doi:10.1371/journal.pone.0007592

Editor: Fabien Tell, The Research Center of Neurobiology - Neurophysiology of Marseille, France

Received June 21, 2009; Accepted September 30, 2009; Published October 26, 2009

Copyright: (c) 2009 Rangel et al. This is an open-access article distributed under the terms of the Creative Commons Attribution License, which permits unrestricted use, distribution, and reproduction in any medium, provided the original author and source are credited.

Funding: This study was supported by grants from MICINN, FISS, Generalitat de Catalunya (SGR2009-366), Junta de Andalucía (CVI-02487), Instituto Carlos III, UE CT2004-506579 and by FP7-EU program (PRIORITY-222887). RG and FLL are Juan de la Cierva researchers from MEC, and AR was supported by the Programme Alban, the European Union Programme of High Level Scholarships for Latin America (E04D034892VE) and the Generalitat de Catalunya. The funders had no role in study design, data collection and analysis, decision to publish, or preparation of the manuscript.

Competing Interests: The authors have declared that no competing interests exist.

*E-mail: jadelrio@ibec.pcb.ub.es (JADR); jmdelgar@upo.es (JMDG)

\section{Introduction}

The cause of spongiform encephalopathy in Creutzfeldt-Jacob disease (CJD), scrapie in sheep or bovine spongiform encephalopathy (BSE) is an abnormal conformational isoform $\left(\operatorname{PrP}^{\mathrm{sc}}\right)$ of the Prnp gene product $\operatorname{PrP}^{\mathrm{c}}$ [1-4]. Although early studies of the behavior of Prmp knockout mice described only minor changes [5], later studies reported that these mice develop an age-dependent impairment in memory consolidation, altered behavior and neurotransmission (see [6,7] for reviews). Several authors reported that excitatory glutamatergic synaptic transmission, $\mathrm{GABA}_{\mathrm{A}}$ receptor-mediated fast inhibition and late afterhyperpolarization were reduced or absent in mice lacking $\operatorname{PrP}^{\mathrm{c}}[8-11]$. However, other authors reported differences in inhibitory and excitatory neurotransmission between Prnp $-/-$ and wild-type mice [12-16]. More recently, the function of $\operatorname{PrP}^{\mathrm{c}}$ in the regulation of olfactory behavior and dendrodendritic synaptic transmission in olfactory neurons has been described [17]. Moreover, Prmp -/- 
mice show synaptic dysfunctions such as altered circadian rhythms and sleep [18], impaired hippocampal dependent spatial learning [19] and age-dependent impairment of memory consolidation [20]. Some of these functions such as memory consolidation are mediated by its receptor [21] and the stress-inducible protein 1 [22]. Here we explore the role of $\operatorname{PrP}^{\mathrm{c}}$ expression in neurotransmission and neural excitability using wild-type, Prmp $-/-$ and $\mathrm{PrP}^{\mathrm{c}}$-overexpressing mice (Tg20 strain). By correlating neurohistopathology with electrophysiology in living behaving mice, we found that Pmp - / - mice but, more relevantly, Tg20 mice show increased susceptibility to KA, leading to relevant cell death in the hippocampus. This finding correlates with enhanced synaptic facilitation and hippocampal LTP in both types of mutant mice. Lastly, our study using Illumina ${ }^{\mathrm{TM}}$ microarrays and further validation with RT-qPCR demonstrate that genes encoding AMPA-kainate and $\mathrm{GABA}_{\mathrm{A}}$-mediated receptors are co-regulated in Prmp $-/-$ and Tg20 mice.

\section{Results}

\section{Different KA sensitivity and severity of KA-induced seizures in Prnp -/-, and Tg20 with respect to wild-type mice}

Mice were treated with KA for 2 h (4 i.p. injections and analyzed for additional $2 \mathrm{~h}$ ). The onset and intensity of seizures induced by identical KA injections differed greatly between mutant (Prnp - /and Tg20) and wild-type mice (Table 1). Although non-statistically significant, Tg20 mice showed a later onset of seizures (95.8 \pm 10.1 min; mean \pm SEM) with respect to Prmp $-/-$ mice (84.6 $\pm 15.19 \mathrm{~min})$. Wild-type mice showed few behavioral changes and only one wild-type mouse showed signs of Grade III seizures after $147 \mathrm{~min}$, which corresponded to the hyperactivity stage (Table 1, see Experimental procedures for details). None of the wildtype mice died during the experiments. In contrast, one Prmp - /and two Tg20 mice had severe seizures and died. The mean number \pm SEM of seizures in treated mice was as follows: $\operatorname{Tg} 20=7.3 \pm 1.8, \operatorname{Prmp}-/-=14.8 \pm 0.9$, and wild-type $=0.3 \pm 0.3$. Although the number of seizures was low, all Tg20 mice showed Grade VI seizures, while Prnp - / - mice showed Grade V-VI. In addition, Tg20 had significantly longer seizures than Prnp - /(33 min for Tg20 and 16 min for Prmp -/-).

\section{Correlation between histological and behavioral effects after KA treatment in experimental mice}

To determine whether the severity of changes in behavior observed in Tg20 and Prmp - / - after KA treatment correlated to neuron death in the hippocampus, we carried out Fluoro Jade-B (FJ-B) histochemical staining in coronal brain sections from KAtreated mice from all three experimental groups (Fig. 1). The pattern of cell death was different in each group. Tg20 mice showed more dying cells than Prnp -/- or wild-type mice. Although most dying cells were observed in the pyramidal layer of the CA1, with fewer in CA3 (Fig. 1), many FJ-B-positive cells were seen in the hilus of the dentate gyrus, the interphase stratum lacunosum moleculare/stratum radiatum (irl) and stratum oriens of the hippocampus proper of Tg20 (Fig. 1A, G). In contrast, dying cells were exclusively observed in the pyramidal layer of the CAl and CA3 regions in Prmp $-/-$ mice (Fig. 1C). Wild-type animals showed no cell death in the hippocampus after the KA-treatment (Fig. 1E). Neurodegeneration in Tg20 and Prmp - /- mice was accompanied by reactive astrogliosis in lesioned regions, determined by increased GFAP-immunostaining (Fig. S1) and ERK1-2 kinase activation in reactive glial cells (not shown).
Table 1. Effects of KA-induced status epilepticus and death in Tg20, Prnp -/-, and wild-type mice.

\begin{tabular}{|c|c|c|c|}
\hline Mice genotype & Onset (min) & $n^{\circ}$ of seizures & Prioritary behavior \\
\hline $\operatorname{Tg} 20$ & 60 & 17 & VI (death) \\
\hline Tg20 & 113 & 5 & $\mathrm{VI}$ \\
\hline Tg20 & 101 & 8 & VI \\
\hline Tg20 & 66 & 4 & VI (death) \\
\hline Tg20 & 121 & 5 & VI \\
\hline Tg20 & 114 & 5 & $\mathrm{VI}$ \\
\hline Wild-type & - & 0 & III \\
\hline Wild-type & 147 & 2 & III \\
\hline Wild-type & - & 0 & III \\
\hline Wild-type & - & 0 & III \\
\hline Wild-type & - & 0 & III \\
\hline Wild-type & - & 0 & III \\
\hline Prnp -/- & 40 & 14 & V-VI \\
\hline Prnp -/- & 118 & 13 & $\mathrm{~V}-\mathrm{VI}$ \\
\hline Prnp -I- & 103 & 19 & $\mathrm{~V}-\mathrm{VI}$ \\
\hline Prnp -/- & 120 & 15 & $\mathrm{~V}-\mathrm{VI}$ \\
\hline Prnp -/- & 100 & 13 & $\mathrm{~V}-\mathrm{VI}$ \\
\hline Prnp -/- & 27 & Continue & V-VI (death) \\
\hline
\end{tabular}

The onset, the number of seizures, the behavioral stages and the time in the prioritary stage is shown in each case. doi:10.1371/journal.pone.0007592.t001

\section{Recording of fEPSPs at the CA3-CA1 synapse in alert behaving $\operatorname{PrP}^{\mathrm{C}}$ mice strains}

Permanently implanted stimulating and recording electrodes in the hippocampus of behaving mice enabled us to follow the evolution of fEPSPs evoked at the CA3-CA1 synapse for several days in the same animal [23,24]. During surgery, recording electrodes were oriented towards the apical dendrites of pyramidal CAl cells (Fig. 2), as indicated by the negative fEPSPs recorded in most cases [24,25]. The final location of recording and stimulating electrodes was checked histologically at the end of the experiments (Fig. S2).

\section{Input/output ratios were modified in Prnp $-/-$, and Tg20 with respect to wild-type mice}

In a preliminary series of experiments, we measured the slope of fEPSPs evoked at the CA1 area by paired-pulse $(40 \mathrm{~ms}$ interstimulus interval) stimulation of Schaffer collaterals at increasing intensities. In wild-type, $(\mathrm{n}=3$ animals; $\mathrm{n}=5$ measurements/ stimulus intensity and animal), the slope of fEPSPs (in $\mathrm{mV} / \mathrm{s}$ ) evoked in the CAl area by the first pulse increased steadily with current strength, to asymptotic values (at $\approx 950 \mathrm{mV} / \mathrm{s}$ ) (Fig. 2). In contrast, fEPSPs evoked by the second pulse increased more or less in parallel with the fEPSPs evoked by the first pulse (but with $\approx 20 \%$ larger values) until a certain stimulus intensity $(\approx 0.15 \mathrm{~mA}$; see insert at Fig. 2A, 1.WT), after which the fEPSP slopes evoked by the second pulse were significantly smaller than those evoked by the first $\left[\mathrm{F}_{(19,38)}=2.313 ; P<0.01\right.$, marked by asterisks in Fig. 2A, 1.WT]. Thus the paired-pulse facilitation evoked at low stimulus intensities in wild-type animals was reverted into a paired-pulse depression at high stimulus intensities. Indeed, as reported recently [26], the paired-pulse ratio $[(2 \mathrm{nd} / 1 \mathrm{st}) \times 100$; see bottom graph at Fig. 2A, 1.WT] decreased steadily from 

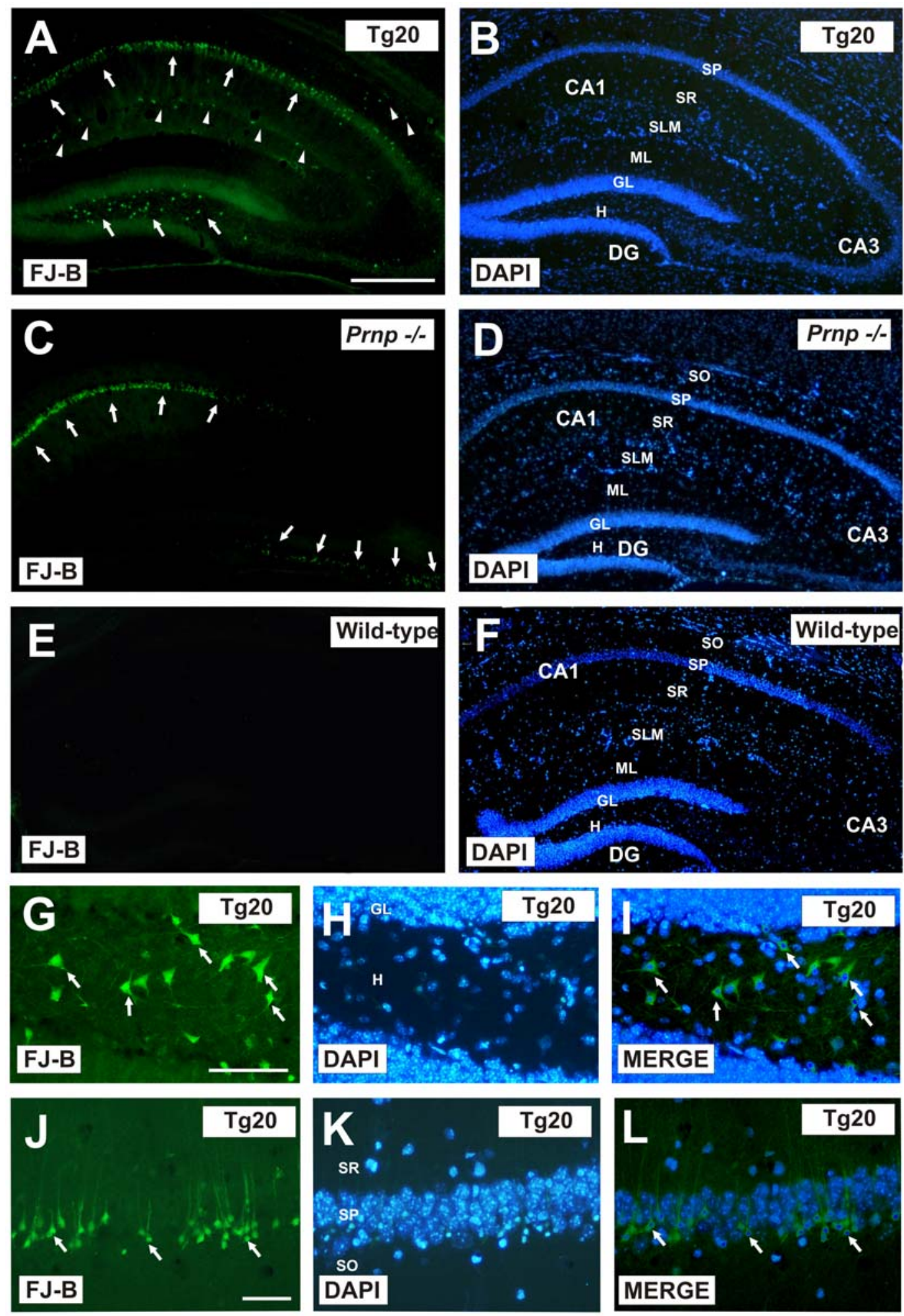

Figure 1. Increased seizure-related histopathology in Prnp -/-, Tg20 and wild-type mice. A-F) Low-power photomicrographs illustrating the pattern of Fluoro Jade-B (FJ-B) labeling $(A, C, E)$ and DAPI $(B, D, F)$ in the hippocampus of Tg20 (A-B), Prnp - /- (C-D) and wild-type (E-F) mice after KA injection. Dying pyramidal neurons (arrows in A and C) labeled with FJ-B were located in the CA1 and CA3 regions in Tg20 and Prnp -/- mice. However, a more widespread distribution of dying cells can be seen in Tg20 hippocampus (arrowheads in A) with hilar cells and subsets of interneurons in CA1-3 being intensely labeled. G-L) High-power photomicrographs illustrating the pattern of Fluoro Jade-B (FJ-B) labeling (G.J) and DAPI $(\mathrm{H}, \mathrm{K})$ in the hilus $(\mathrm{G}-\mathrm{I})$ and the CA1 (J-L) of Tg20 mice after KA injection. Numerous neurons labeled with Fluoro Jade-B (arrows in G,J and I,J) displayed condensed chromatin, as ascertained by DAPI staining (H-I, K-L) Abbreviations: CA1-3 hippocampal fields 1-3, DG, dentate gyrus; gl, granule cells; h, hilus; $\mathrm{ml}$, molecular layer; sp; stratum pyramidale; sr, stratum radiatum; slm, stratum lacunosum moleculare; so, stratum oriens. Scale bars $\mathrm{A}=250 \mu \mathrm{m}$ pertains to $\mathrm{B}-\mathrm{F} . \mathrm{G}=100 \mu \mathrm{m}$ pertains to $\mathrm{H}-\mathrm{l} ; \mathrm{J}=150 \mathrm{~mm}$ pertains to $\mathrm{I}-\mathrm{L}$.

doi:10.1371/journal.pone.0007592.g001 
A. CONTROL
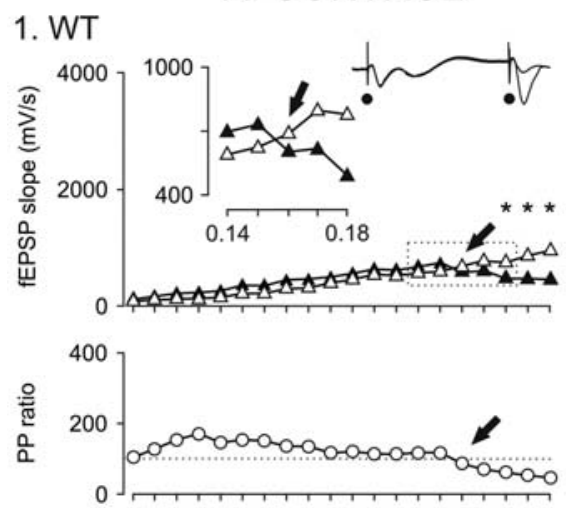

\section{Prnp -/-}
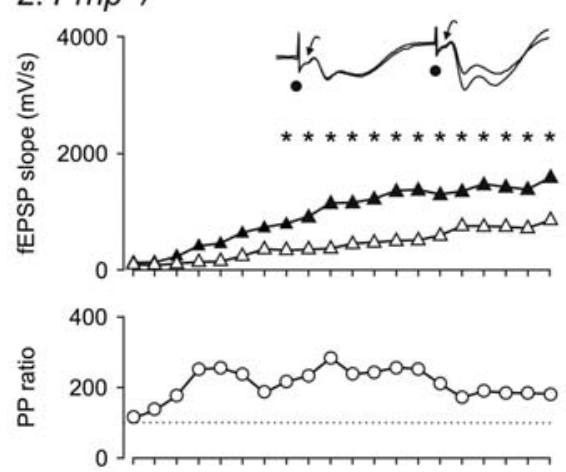

3. $\operatorname{Tg} 20$
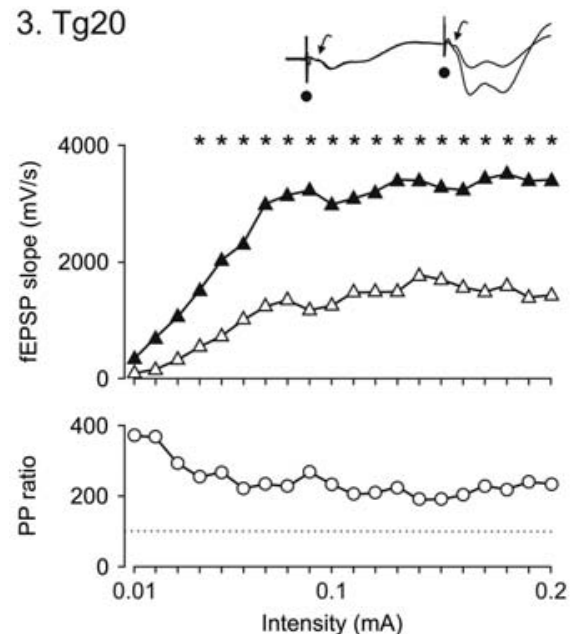

B. KAINATE
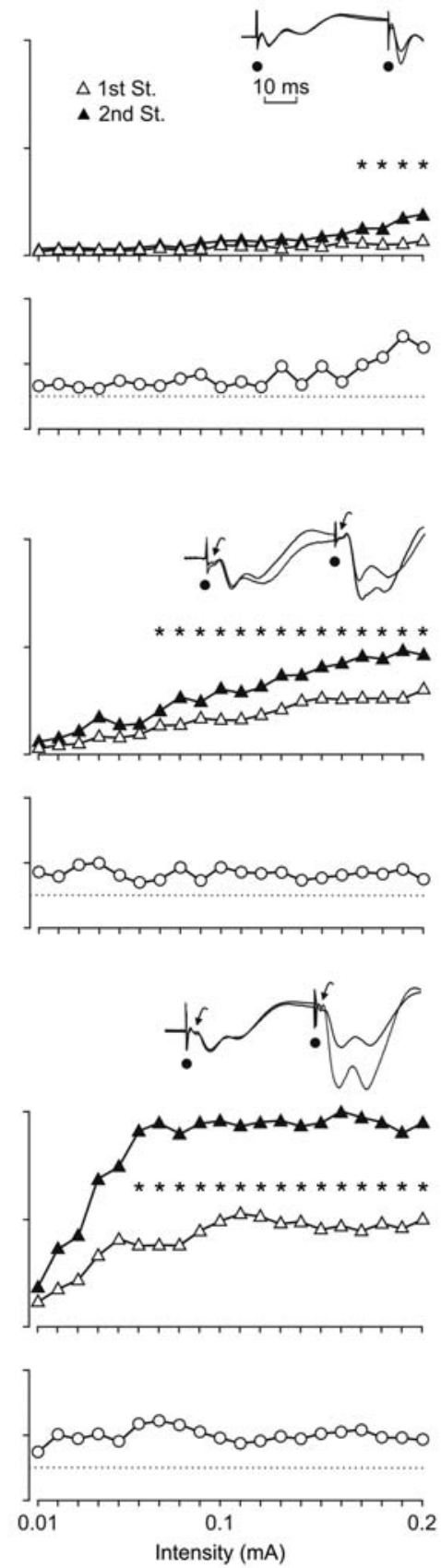

Figure 2. Input/output curves of the CA3-CA1 synapse using paired-pulse stimulation in wild-type (WT), Prnp -I-, and Tg20 mice before $(A)$ and after $(B)$ the administration of kainate (KA). A) Relationships between the intensity (from 0.01 to $0.2 \mathrm{~mA}$ ) of pairs of stimuli ( $40 \mathrm{~ms}$ inter-stimulus interval) presented to Schaffer collaterals and the slope (in mV/s) of fEPSPs evoked at the CA1 layer, corresponding to the $1 \mathrm{st}$ (white triangles) and the 2nd (black triangles) pulses. Data were collected from WT (1.), Prnp $-/-(2$.$) and Tg20 (3.) mice ( \mathrm{n}=3$ animals/group; $\mathrm{n}=5$ measurements/animal). The paired-pulse ratio was calculated as $[(2 \mathrm{nd} / 1 \mathrm{st}) \times 100]$ and it is illustrated for each group in the lower plot (white circles). Arrows in 1.WT indicate the intensity at which the paired-pulse evoked facilitation was reversed into depression. The inset in 1.WT is an enlargement of the dotted area, to illustrate the switch from paired-pulse facilitation to paired-pulse depression. Note that this reversal was not present in Prnp $-/-$ or Tg20 groups, in which the second pulse was significantly larger than the first for most of the stimulation range. Representative averaged $(n=3)$ records of fEPSPs recorded in the CA1 area following paired (1st and 2nd St., at 40 ms inter-stimulus interval) stimulation of the ipsilateral Schaffer collaterals at two different $(0.05 \mathrm{~mA}$ and $0.18 \mathrm{~mA})$ intensities are illustrated for the three experimental groups. For comparative purposes, fEPSPs evoked by the 1st pulse were adjusted to the same amplitude. Dots indicate stimulus artifacts and bent arrows indicate the presence of afferent volleys. B) Same set of experiments as illustrated in A, but $30 \mathrm{~min}$ after a single injection of KA (8 mg/kg, i.p.). Note that KA did not significantly increase fEPSPs evoked by the 1st or the 2nd pulses in any of the 3 experimental groups. Asterisks indicate significant differences $(P \leq 0.05)$ between fEPSPs evoked by the 1 st versus the 2 nd pulse.

doi:10.1371/journal.pone.0007592.g002 
facilitation to depression with an inflexion point at $\approx 0.15 \mathrm{~mA}$ (arrows in Fig. 2A, 1.WT). It has been suggested that the switch from facilitation to depression evoked by paired-pulse stimulation of increasing intensity is part of a protective and/or balancing homeostatic mechanism present in hippocampal synapses [27].

Input/output curves evoked at the CA3-CA1 synapse in Prnp-/- animals ( $\mathrm{n}=3$ animals; $\mathrm{n}=5$ measurements/animal) were different in amplitude and profile from those evoked in wildtype mice. In the Prmp -/- group both the 1st and 2nd pulse evoked fEPSPs slopes greater than the corresponding values collected from wild-type (Fig. 2A, 2. Prmp-/-). Moreover, the slope of fEPSPs evoked by the 2nd pulse was significantly greater than those evoked by the 1st pulse over a wide range of stimulus intensities $\left[0.08-02 \mathrm{~mA} ; \mathrm{F}_{(19,38)}=4.123 ; P<0.001 ;\right.$ Fig. 2A, 2. Prmp - / - upper graph]. More importantly, the paired-pulse ratio in Prnp - /- mice did not present a decreasing profile with the progressive increase in stimulus intensity (Fig. 2A, 2. Prmp -/-, bottom graph).

Finally, input/output relationships evoked at the CA3-CA1 synapse in the Tg20 group ( $\mathrm{n}=3$ animals; $\mathrm{n}=5$ measurements/ animal) were $\approx 3$ times larger in fEPSP slopes than in the wild type group $\left[\mathrm{F}_{(38,76)}=2.863 ; P<0.001\right.$; Fig. $2 \mathrm{~A}, 1$.WT vs. Fig. $2 \mathrm{~A}, 3$. Tg20 graphs]. Moreover, asymptotic values were reached at lower stimulus intensities $(\approx 0.07 \mathrm{~mA}$ for the Tg20 group $v s$. $\approx 0.16 \mathrm{~mA}$ for the wild-type group). The slope of fEPSPs evoked by the 2 nd pulse in the Tg20 group was significantly greater than those evoked by the 1st pulse over a wide range of stimulus intensities [0.05-0.2 mA; $\mathrm{F}_{(19,38)}=4.517 ; P<0.001 ;$ Fig. $2 \mathrm{~A}, 3$. Tg20, upper graph]. Finally, the paired-pulse ratio in Tg20 mice showed a decreasing profile with the progressive increase in stimulus intensity, but always in the paired-pulse facilitation range (Fig. 2A, 3. Tg20, bottom graph). In summary, Prmp - /and Tg20 mice presented significantly different input/output curves from wild-type, with a strong increase in paired-pulse facilitation and with the disappearance of the balancing homeostatic mechanism already described at CA3-CA1 in wildtype mice [26].

\section{Effects of a single KA injection on input/output relationships at the CA3-CA1 synapse in the three experimental groups}

As reported above Prmp - /- and Tg20 mice showed increased sensitivity to KA-induced seizures. In order to discern the effects of a relative low dose of $\mathrm{KA}$ on input/output curves, we repeated the experiment illustrated in Fig. 2A, but $30 \mathrm{~min}$ after a single injection of $\mathrm{KA}(8 \mathrm{mg} / \mathrm{kg}$, i.p.). KA injection produced slight changes in the profiles of input/output relationships evoked in wild-type, Prnp - / - and Tg20 animals (Fig. 2B). The paired-pulse depression evoked in the wild-type group disappeared at higher stimulus intensities (compare the upper graphs in Figs. 2A and 2B, for the wild-type group, 1.WT). Indeed, fEPSP slopes evoked by the 2nd pulse at high intensities in wild-type animals were significantly greater than the corresponding values for the 1 st pulse $\left[0.17-0.2 \mathrm{~mA} ; \mathrm{F}_{(19,38)}=1.749 ; P \leq 0.05\right.$; Fig. 2A, B, 1.WT, upper graph]. No significant differences were observed between input/ output curves evoked in Prnp - / - or Tg20 mice before or after KA injections. Thus, KA injection apparently disrupted the protective facilitation/depression mechanism evidenced by pairedpulse stimulation at increasing intensities [27], but did not affect fEPSPs evoked at the CA3-CA1 synapse in Prnp - / - or Tg20 mice, because this balancing mechanism is already disrupted and/ or occluded in the latter animals.
Prnp $-/-$ and Tg20 mice presented more paired-pulse facilitation than wild-type mice

The facilitation evoked by the presentation of a pair of pulses is a typical presynaptic short-term plastic property of some excitatory synapses, including the hippocampal CA3-CAl synapses, and it has been correlated with neurotransmitter release [28]. As reported, recently, this contention can only be sustained at low stimulus intensities [26]. For this reason, we checked paired-pulse facilitation in the three groups of animals at different $(10,20,50$, 100, 200, and $500 \mathrm{~ms}$ ) inter-stimulus intervals, but setting the stimulus intensity at $30-40 \%$ of the amount needed to reach asymptotic values $[23,29]$. In this situation, wild-type animals were expected to present a larger fEPSP response to the 2nd (with respect to the $1 \mathrm{st})$ stimulus at short intervals $(<100 \mathrm{~ms})$. Wild-type mice presented a significant $\left[\mathrm{F}_{(5)}=54.810 ; P<0.01\right]$ increase in the response to the 2nd pulse at the $40-\mathrm{ms}$ interval (Fig. 3A). $\operatorname{Prn} p-/-$ mice also presented significant paired-pulse facilitation at the 40 -ms interval $(P<0.01$; Fig. 3A, 2. Prmp $-/-)$, whilst Tg20 mice presented significant paired-pulse facilitation at several $(10$, 20, 40) short inter-stimulus intervals $(P<0.01$; Fig. 3A, 3.Tg20). Paired-pulse facilitation at the $40 \mathrm{~ms}$ interval was significantly larger in Pmp $-/-$ and Tg20 animals than in wild-type mice $\left[\mathrm{F}_{(10,20)}=3.040 ; P \leq 0.01\right]$. KA injection did not significantly modify paired-pulse facilitation in wild-type and $\operatorname{Prmp}-/-$ animals, but evoked a facilitation at medium (100 ms) interstimulus intervals in Tg20 mice $\left[\mathrm{F}_{(10,20)}=4.507 ; P \leq 0.002\right]$. In short, Prnp $-/-$ and Tg20 presented more facilitation during the paired-pulse test than wild-type both in the absence and in the presence of a KA injection.

\section{LTP of the CA3-CA1 synapse is increased in Prnp -/- and Tg20 mice}

For the LTP study, animals were stimulated at Schaffer collaterals every $20 \mathrm{~s}$ for $\geq 15 \mathrm{~min}$, until a stable fEPSP was recorded (baseline, Fig. 4A). The stimulus consisted of a double (100 $\mu$ s, square, and biphasic) pulse presented at an interval of $40 \mathrm{~ms}$ [24]. Pulse intensity $(30-110 \mu \mathrm{A})$ was set at $30-40 \%$ of the amount necessary to evoke a maximum fEPSP response [23]. For LTP induction, each animal was presented with a high-frequency stimulation (HFS) session consisting of five trains (200 Hz, $100 \mathrm{~ms}$ ) of pulses at a rate of $1 / \mathrm{s}$. This protocol was presented 6 times in total, at intervals of $1 \mathrm{~min}$. In order to avoid evoking a population spike and unwanted EEG seizures, the stimulus intensity for HFS was set at the same amount used for generating the baseline record. After HFS, the same single stimulus used to generate baseline records was presented at the initial rate $(3 / \mathrm{min})$ for another $30 \mathrm{~min}$. Field EPSPs were checked for a further 15 minutes, $24 \mathrm{~h}$ and $48 \mathrm{~h}$ after the HFS session (Fig. 4A). Since short-term potentiation seems to be dependent on the number of stimuli [30], paired-pulse evolution after HFS was monitored using a minimum number of paired stimuli per recording session (i.e., a maximum of 90 pairedpulses per recording day). Using this protocol, the three experimental groups presented a significant LTP lasting $>24 \mathrm{~h}$ for both the 1 st and the 2nd pulses [wild-type: $\mathrm{F}_{(14)}=14.048, P<0.001$. Prmp - / : $\mathrm{F}_{(14)}=0.982, P<0.001$. Tg20: $\mathrm{F}_{(14)}=12.509, P<0.001$; Fig. 4A]. However, Tg20 presented significantly larger potentiation to the 1 st and, mostly, to the 2nd pulse following the HFS session as compared with the wild-type $\left[\mathrm{F}_{(6,42)}=1.388, P<0.01\right.$ for the 1 st pulse and $\mathrm{F}_{(6,42)}=1.423, P<0.01$ for the 2nd pulse; Fig. 4B]. Values recorded in Prnp $-/-$ mice were also higher (but not significantly) than wild-type.

It has been reported that HFS can modify the paired-pulse ratio, possibly as a result of competition with presynaptic release 


\section{A. CONTROL}

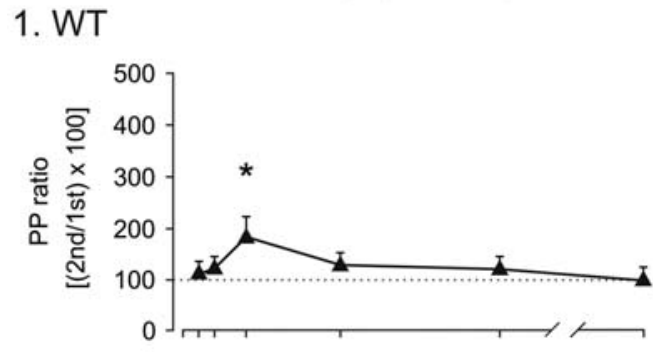

\section{Prnp -/-}

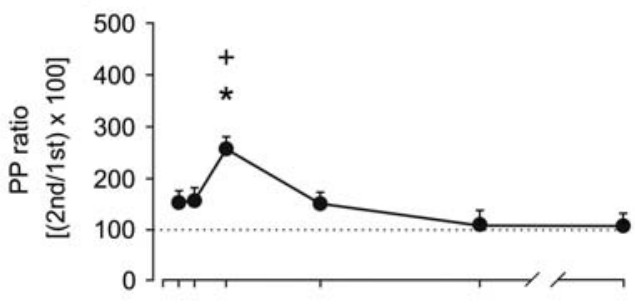

\section{3. $\operatorname{Tg} 20$}

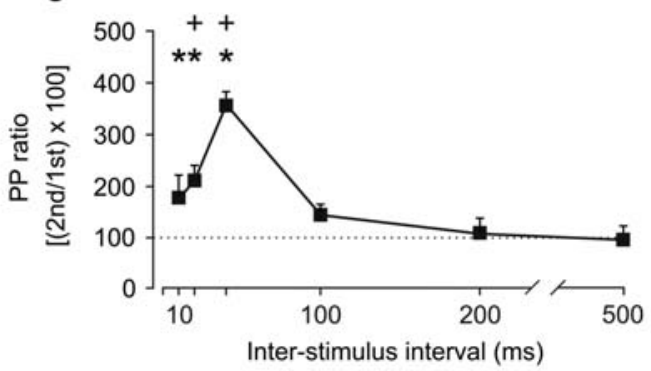

\section{B. KAINATE}
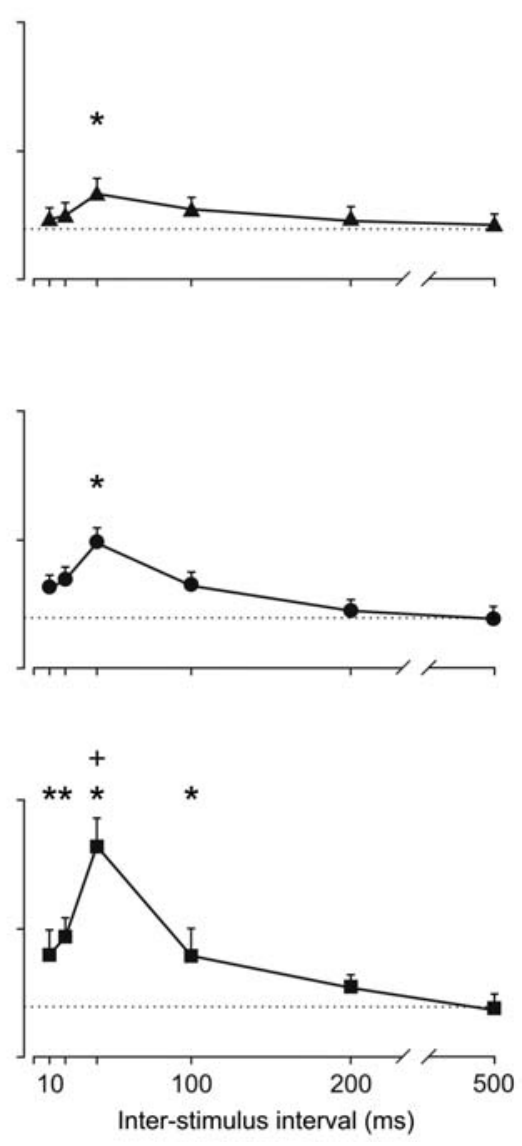

Figure 3. Effects of paired-pulse stimulation of the CA3-CA1 synapse at different inter-stimulus intervals for the three experimental groups before and after the administration of kainate (KA). A) Paired-pulse facilitation collected from wild-type (WT; 1, black triangles), Prnp $-/-(2$, black circles) and Tg20 (3, black squares) mice $(n=3$ animals/group; $n=5$ measurements/animal) in the control situation. Thus, each point indicates the mean value for 15 records \pm SEM. B) Same set of experiments carried out $30 \mathrm{~min}$ after a single injection of KA (8 mg/kg, i.p.). Asterisks indicate significant differences $(P \leq 0.01)$ between fEPSPs evoked by the 2 nd pulse as compared with those evoked by the 1 st, for the three experimental groups. The plus signs indicate significant differences $(P \leq 0.001)$ between the amount of facilitation evoked in Tg20 and Prnp $-/-$ groups as compared with the WT group.

doi:10.1371/journal.pone.0007592.g003

mechanisms [24,30-32]. This suggestion was clearly confirmed here for HFS modified the paired-pulse ratio in $\mathrm{Tg} 20$ and Prnp $-/-$ animals (Fig. 3C), but not in the wild-type group. A consequence of the latter result could be the rather small facilitation obtained in this group during baseline records. Moreover, HFS in Prmp $-/-$ and mainly in Tg20 mice evoked a greater paired-pulse facilitation than in wild-type mice, even after LTP induction.

Microarray analysis of gene expression and identification of canonical pathways by Ingenuity ${ }^{\mathrm{TM}}$ pathways analysis (IPA) in the three experimental groups

We used SAM software to identify genes that were differentially expressed in the untreated hippocampi of the three phenotypes. Thus, Tg20 mice had 336 genes that were de-regulated compared to wild-type mice. 207 of these were specific to Tg20 and the rest (129) were shared with Prmp - / - (Fig. S3). In addition, Prmp - /showed 404 genes that were de-regulated in comparison with wildtype, of which 275 were specific to Prmp - / - and 129 were shared with Tg20 (Fig. S3). The 129 genes shared by Prmp - / - and Tg20 mice are co-regulated in the same way (up- or down-regulated) (Fig. S3). Next, we used the Web-based on line tool IPA to identify the set of biological pathways that were regulated in our experiment by integrating gene expression profiles using gene ontology (GO). As illustrated in Fig. S3, the list of significant canonical pathways containing co-regulated genes in Tg20 and Prnp - / mice included: Protein Ubiquitination Pathways, Glycerolphospholipid Metabolism, Nitrogen Metabolism, GABA Receptor Signaling, D-Glutamine and D-Glutamate Metabolism, Glutamate Receptor Signaling, B-Cell Receptor Signaling, Hypoxia Signaling in the Cardiovascular System and Calcium Signaling. (Fig. S3).

\section{Differential expression of Glutamate and $\mathrm{GABA}_{\mathrm{A}}$ receptors in prion mice strains}

Illumina Sentrix 6 mouse v2 beadarrays contain probes for some of AMPA-Kainate receptor subunits but, unfortunately not all subunits are represented (e.g., GluR6 and GluR7). In addition, any minor deregulation in specific genes cannot be determined since it may be masked in the hybridization procedure. However, 
A

1. WT

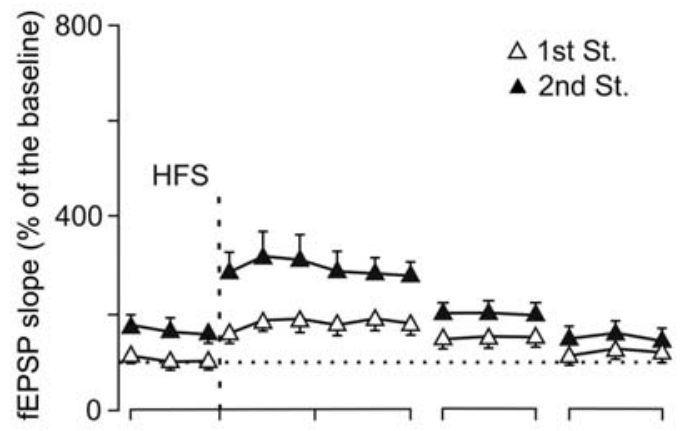

2. Prnp -/-

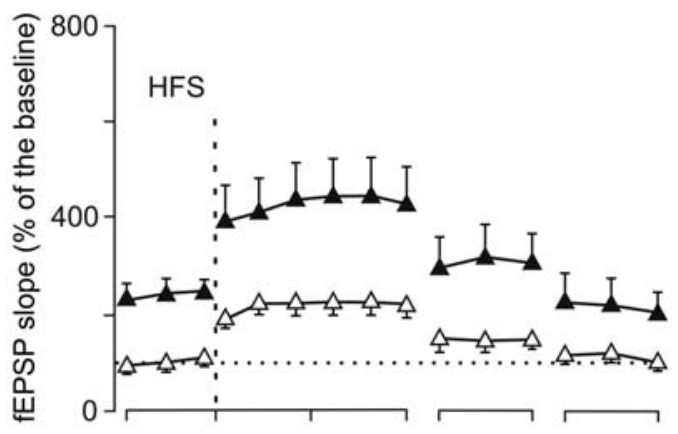

3. $\operatorname{Tg} 20$

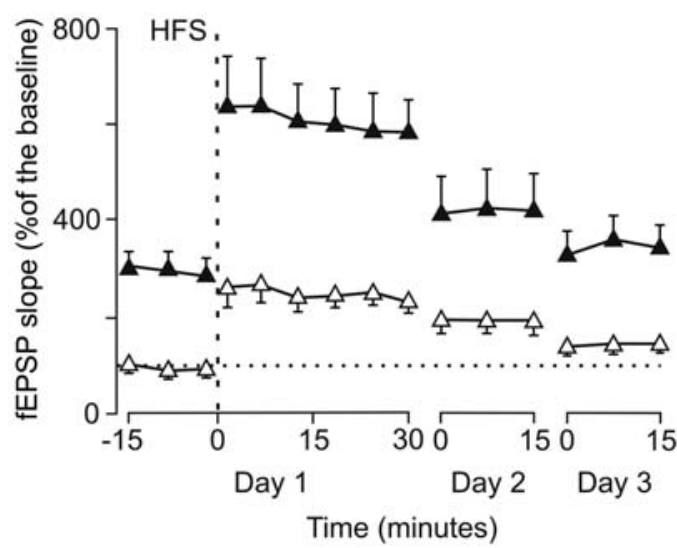

1st pulse

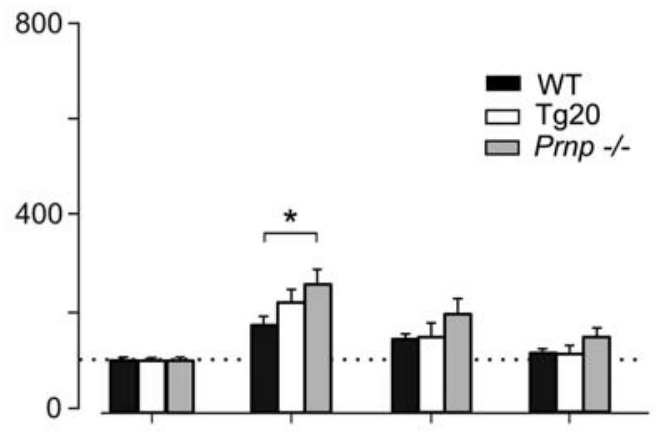

2nd pulse
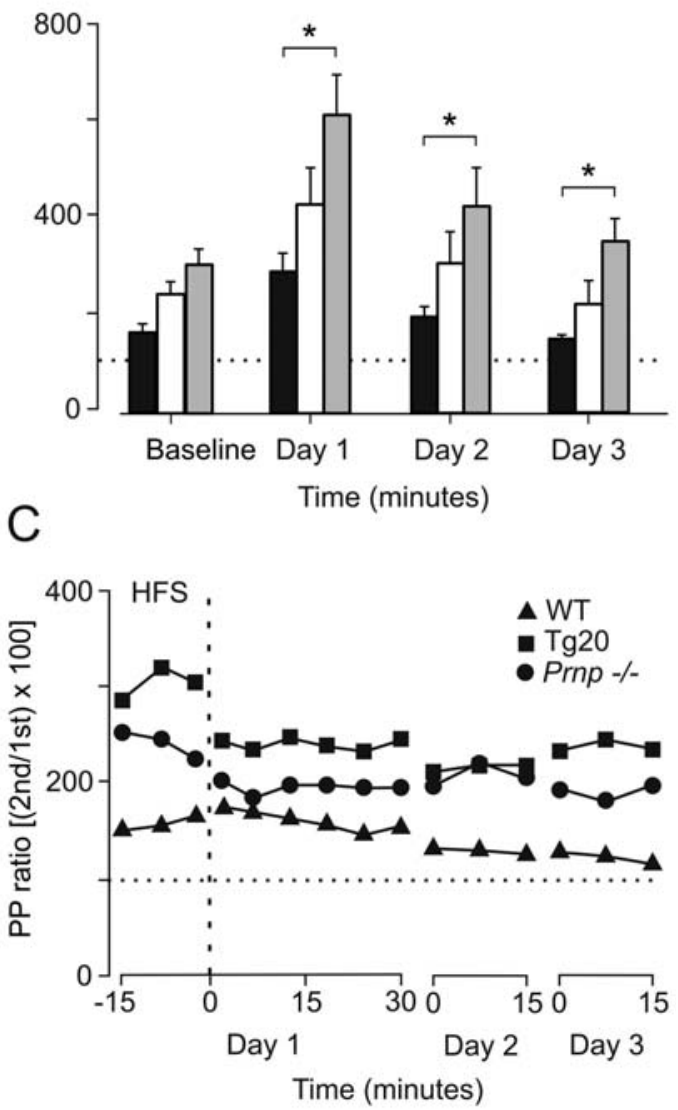

Figure 4. Evolution of fEPSPs evoked in the CA1 area by paired-pulse stimulation of Schaffer collaterals for the three experimental groups before and after a HFS session. A) Graphs illustrating the time course of changes in fEPSPs (mean \pm SEM) following HFS stimulation of the Schaffer collaterals. The HFS train was presented after $15 \mathrm{~min}$ of baseline recordings, at the time marked by the dashed line and consisted of five $200 \mathrm{~Hz}, 100 \mathrm{~ms}$ trains of pulses at a rate of 1/s. This protocol was presented six times, at intervals of $1 \mathrm{~min}$. fEPSPs are given as a percentage of the baseline (100\%) slope. LTP evoked in WT (1.), Prnp - /- (2.), and Tg20 (3.) mice ( $\mathrm{n}=8$ animals per group). The $100 \mu$ s, square, biphasic pulses used to evoke LTP were applied at the same intensity as that used for the single pulse presented following HFS presentation. The evolution of LTP was confirmed using a pair of pulses (1st, white triangles; 2 nd, black triangles) with an inter-stimulus interval of 40 ms. Recordings were carried out for $30 \mathrm{~min}$ after the HFS session, and repeated for $15 \mathrm{~min} 24 \mathrm{~h}$ and $48 \mathrm{~h}$ later. B) Quantitative analysis of fEPSP evolution at the indicated times for the three experimental groups. Field EPSPs evoked by the 1st (top diagram) and the 2nd (bottom diagram) pulses are indicated separately. Asterisks indicate significant differences between groups $(P \leq 0.01)$. C) Evolution of the paired-pulse ratio $[(2 \mathrm{nd} / 1 \mathrm{st}) \times 100]$ for WT (black triangles), Prnp $-/-$ (black circles), and Tg20 (black squares) groups. Note that fEPSP slopes decreased across recording days for both 1 st and 2nd pulses, but that their relationship $\left[(2 \mathrm{nd} / 1 \mathrm{st}) \times 100\right.$; white circles] increased steadily over time. Illustrated data correspond to mean $\pm S E M *, P<0.001$, $\left[F_{(12,108)}=13.463\right]$ for differences between the 1 st and 2 nd pulses.

doi:10.1371/journal.pone.0007592.g004 
GluR 1 and $\mathrm{GABA}_{\mathrm{A}}-\gamma 2$ were among the 129 co-regulated genes. Thus we used RT-qPCR to extend the analysis to all glutamate and $\mathrm{GABA}_{\mathrm{A}}$ receptors (Fig. 5). First, Prmp expression levels in the hippocampus were analyzed in wild-type and Tg20 samples and Prnp - /- mice by RT-pPGR (Fig. 5A-B). There was a 4.9 fold increase in Prnp-expression in Tg20 compared to wild-type whereas Prmp was not detected in Prmp - / - mice. Next, we analyzed the differential expression of AMPA-Kainate and NMDA receptor subunits (NR1, NR2A and NR2B) and GABA receptors subunits by RT-qPCR using specific primers (Table $\mathrm{S} 1$ ). GluR 1 subunit was up-regulated 1.3 fold and 2 fold in Tg20 and Pmp - / - mice respectively compared to wild-type animals. In contrast, GluR2 was down-regulated in Tg20 (0.5 fold) and Prmp $-/-(0.7$ fold $)$ compared to wild-type. GluR6 increased in Tg20 (6.5 fold) and in Prmp - / - (2.5 fold). In addition, GluR7 was also overexpressed in Tg20 and Prnp - /- (1.5 fold increase in both cases). Kainate receptor subunits 1 and 2 were up-regulated in Prmp $-/-$ mice (1.2 fold increase (KARl and 2)) and downregulated in Tg20 mice $[0.62$ (KAR1) and 0.3 (KAR2) fold respectively]. NR1 was up-regulated 2 fold in Prmp - /- and 1.5 fold in Tg20; NR2A and NR2B subunits were inversely regulated in Tg20 and Prmp - / - mice. NR2A was up-regulated 2.5 fold in Tg20 and down-regulated 0.7 fold in Prnp - / - In contrast, NR2B was inversely regulated, with a 2.5 fold increase in Prmp $-/-$ and a decrease ( 0.3 fold) in Tg20 an imals.

For $\mathrm{GABA}_{\mathrm{A}}$ receptors, the receptor subunit $\alpha \mathrm{l}$ was overexpressed in Pmp $-/-(1.4$ fold increase $)$ and down-regulated in Tg20 (0.7 fold) with respect to wild-type mice. The expression of $\mathrm{GABA}_{\mathrm{A}}-\delta$ in mutant mice was similar to those seen in $\alpha 1$ : downregulated in $\operatorname{Tg} 20$ (0.62 fold) and over-expressed in Prmp - /mice (1.4 fold). Finally, GABA $\mathrm{A}^{-} \gamma 2$ was strongly up-regulated in Tg20 (4.5 fold increase) and increased in Prmp $-/-$ (2 fold increase). We conclude that $\mathrm{Tg} 20$ and Prmp $-/-$ animals overexpress GluR1, GluR6 and GluR7 and GABA $A_{A}-\gamma 2$ subunits and down-regulate GluR2. In addition, $\mathrm{GABA}_{\mathrm{A}}-\alpha 1$ and $\mathrm{GABA}_{\mathrm{A}}-\delta$ as well as KAR1 and KAR2 are up-regulated in Prnp $-/-$ but down-regulated in Tg20 compared to wild-type.

\section{Discussion}

Most studies of the synaptic functions of $\operatorname{Pr}^{\mathrm{c}}$ have compared Prnp - /- mice (Zürich 1 or Edinburgh strains) with wild-type animals (see Introduction). The results have highlighted the antioxidative function and neuroprotective roles of $\operatorname{Pr}^{\mathrm{c}}$ (e.g., see $[6,7,33,34]$ for reviews). Previous studies have shown that Prnp $-/-$ mice are more susceptible to KA injections than wild-type $[35,36]$. Here we hypothesized that the overexpression of $\mathrm{PrP}^{\mathrm{c}}$ would enhance cell survival by decreasing the susceptibility to KA observed in knockout mice.

In order to test this hypothesis, we compared Tg20, Prmp - /and wild-type mice to examine the effect of Prmp dosage on KAmediated neurotoxicity. Surprisingly, our results did not vindicate our hypothesis because increased Prmp dosage (4.9 fold increase) in Tg20 mice led to stronger reactions to KA-treatment (e.g., epileptic behavior and cell death) than those observed in Prnp- /or wild-type mice. For this reason, we compared these new data with those obtained after electrophysiological recording at the hippocampal CA3-CA1 synapse of living behaving mice and with parallel RT-qPCR of glutamate and $\mathrm{GABA}_{\mathrm{A}}$ receptors in the hippocampus of these mice after a microarray analysis. We found increased cell death in the hippocampus of both $\mathrm{Tg} 20$ and knockout mice after KA-treatment compared to wild-type mice. For this reason, in addition to the neuroprotective functions reported for $\operatorname{PrP}^{c}$ (e.g., $\left.[37,38]\right)$, our results demonstrate that $\operatorname{PrP}^{\mathrm{c}}$ levels play a crucial role in controlling neuronal homeostasis and cell survival. Prnp dosage should be maintained to a certain levels that, when modified, leads to dramatic neurological defects. In $\operatorname{Pr} p-/-$ mice the re-expression of a single allele of the Prmp gene rescues the KA-susceptible phenotype of $\operatorname{Prmp}-/-$ mice [35] and behavioral deficits [19]. For $\operatorname{PrP}^{\mathrm{c}}$-deficient mice we can consider a "loss of function phenotype". However, our results from Tg20 mice are more difficult to reconcile with current knowledge of $\operatorname{PrP}^{\mathrm{c}}$ physiology. In addition, our data show that Tg20 mice are more susceptible to KA than Prnp -/ - Whether these unexpected results in Tg20 mice are attributable to a "loss of function," or a "masking" effect of endogenous $\operatorname{PrP}^{\mathrm{c}}$ roles by the increased Prnp over-expression, or a gain of "neurotoxic" properties by high $\operatorname{PrP}^{\mathrm{c}}$ levels warrants further study.

Tg20 mice showed enhanced neurotoxicity in the hippocampal formation but especially in cell types that were not affected in KAtreated knockout mice, such as interneurons, or hilar cells. This indicates a gain of function process in terms of susceptibility rather than a loss of function phenomena, at least for certain hippocampal cells, since in KA-treated Prmp - / - hippocampus such cells are healthy. In this scenario, two results should be taken into account. First, transient over-expression of $\mathrm{PrP}^{\mathrm{c}}$ in nonneuronal cell lines activates apoptotic stimuli and cell death [39]. Second, some mouse models overexpressing non-mutated forms of $\operatorname{PrP}^{c}$ [40-42] displayed neurodegenerative symptoms. Taken together, these results reinforce the notion that enhanced $\operatorname{PrP}^{\mathrm{c}}$ overexpression may impair cell homeostasis in vitro and in vivo. Although we have not analyzed them in detail, these two results may be generated by different mechanisms. Overexpression of $\operatorname{PrP}^{c}$ may increase $\operatorname{PrP}^{c}$ levels at lipid rafts of the plasma membrane, which may alter intracellular signaling cascades or redox homeostasis, leading to caspase activation. Enhanced signaling by antibody-mediated $\operatorname{Pr}^{\mathrm{C}}$-aggregation triggers cell death by increasing the generation of reactive oxygen species (ROS) [43,44]. In contrast, in some $\mathrm{PrP}^{\mathrm{c}}$-overexpressing mice, enhanced $\operatorname{PrP}^{\mathrm{c}}$ presence may lead to abnormal $\operatorname{PrP}^{\mathrm{C}}$ aggregation, which would contribute to the neural deficits reported [41].

To date, most functional $\operatorname{PrP}^{\mathrm{c}}$ studies on synaptic plasticity have been performed in vitro. To our knowledge, only one electrophysiological study has been performed in vivo - that by Curtis and coworkers. They reported no significant differences in paired-pulse facilitation or LTP in the CAl region after Schaffer collateral/ commissural pathway stimulation. However, they found reduced LTP in the CAl of older Prmp - /- mice compared to wild-type [16]. Here, we report that young-adult Tg20, but not Prnp - /-, mice presented significantly larger potentiation to the 1 st and, especially, to the 2nd pulse following HFS of the CA3-CA1 synapse, compared to wild-type. In contrast to the data reported by Curtis et al. (2003) in anesthetized animals, Prnp - /- mice presented more synaptic facilitation in the paired-pulse test than wild-type, a variation that could simply reflect the different functional (anesthetized vs. alert) states. On the other hand, a recent study by Powell et al., indicates that $\mathrm{Ca}^{2+}$ stores are altered in Prnp - / - mice, which may explain some of the phenotypes identified in $\operatorname{Prmp}-/-$ mice (i.e., weaker slow afterhyperpolarizations (AHP) in hippocampal neurons) [45]. This AHP defect is not caused by voltage-dependent calcium channels or calciumactivated potassium channels as previously suggested [9]. Since AHP is a natural mechanism that modulates successive action potential firing it is reasonable to expect higher susceptibility in $\operatorname{Prn} p-1-$ mice to epileptic treatments and synapse potentiation. Although an early study reported a role of $\operatorname{PrP}^{\mathrm{c}}$ in the regulation of $\mathrm{Ca}^{2+}$ stores in synaptosomal fractions [46], and some pathological effects of aggregated synthetic prion peptides treatments have been 


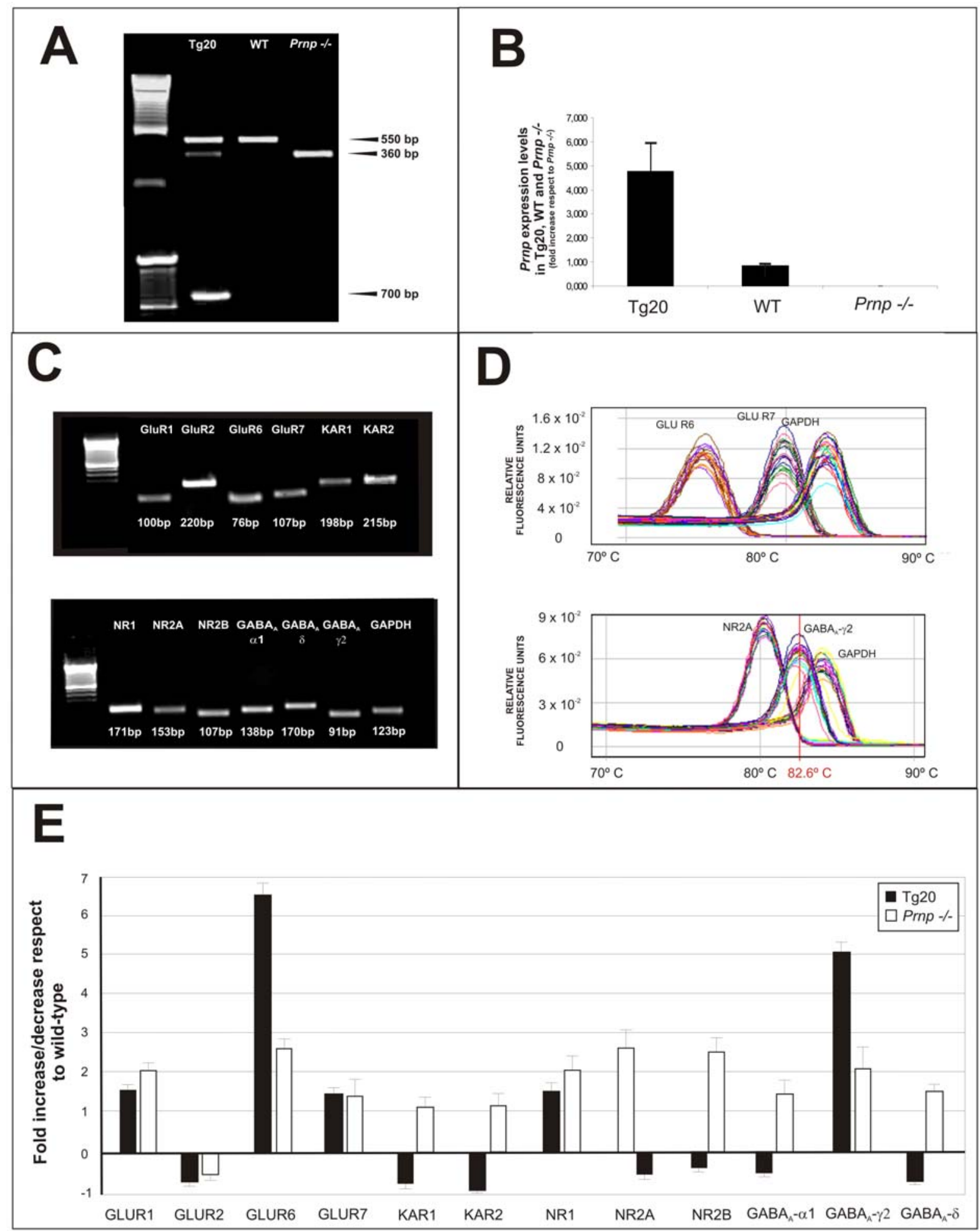

Figure 5. RNA expression of NMDA, AMPA, KA and GABA ${ }_{A}$ receptors in Tg20, Prnp -/- and wild-type mice. A) Agarose gel showing the amplified products of mice genotyping. B) Histograms showing the level of expression of Prnp mRNA obtained by RT-qPCR in each genotype (Tg20, Prnp -/- and wild-type). C) Agarose gel of the amplified products using the Sybr Green RT-qPCR primers for GluR1, GluR2, GluR6, GluR7, KAR1, KAR2, NR1, NR2A, NR2B, GABA $A-\alpha 1, G A B A_{A}-\delta, G A B A_{A}-\gamma 2$ and GAPDH. The size of the amplified bands is indicated in each lane in $B$. GADPH was used as internal control. D) Examples of the melting point analysis of the amplified products for GluR6, GluR7, NR2A, GABA $A_{A}-\gamma 2$ and GADPH. Note the presence of different curves for each gene. The mean temperature for $G_{A B A}-\gamma 2$ is shown as an example. E) Histogram illustrating the quantitative results of the RT-qPCR experiment of target mRNA levels. Histograms represent the mean \pm SEM of three independent experiments correlating receptor subunits/GADPH levels by using the $2^{-\Delta \Delta C t}$ method. Fold increases or decreases were calculated with respect to wild-type data. doi:10.1371/journal.pone.0007592.g005 
associated with the endoplasmic reticulum [47], whether enhanced $\operatorname{PrP}^{\mathrm{C}}$ expression alters intracellular $\mathrm{Ca}^{2+}$ stores in Tg20 mice is still unknown.

On the other hand, the enhanced excitability in Tg20 and Prnp $-/-$ mice can be mediated by the differential expression of specific glutamate or $\mathrm{GABA}_{\mathrm{A}}$ subunit receptors. Indeed GluR2 down-regulation observed in both mice is currently associated with high neuronal excitability (e.g., [48]). In addition, the upregulation of GluR6 [49] and $\mathrm{GABA}_{\mathrm{A}}-\gamma 2$ [50] is also correlated with higher excitability. All these receptor subunits are coregulated in Tg20 and Pmp $-/-$ mice. However, the distribution of FJ-B-positive dying cells in the hippocampus is different in Tg20 and Prnp - / - mice, especially in CA3 and interneurons of CA13 , and in hilar cells. These differences may reflect the particular distribution of the different glutamate receptors in the hippocampus and the specific participation of AMPA or kainate receptors as well as NMDA receptors in the KA-induced effects [51,52]. For example, in addition to the co-regulation of GluR1-2 and Glur6GluR7 subunits, Pmp -/- mice increased KAR1 and KAR2 receptor subunits compared to Tg20. In contrast, both mice displayed increased expression of NR1, but Prmp - / - displayed enhanced NR2B expression. The distribution of NR1 in the hippocampus closely follows the distribution of NR2A and NR2B $[53,54]$. However, recent studies reported that NMDA receptors play special role in CA3 recurrent networks with relevant roles in seizure generation [55]. In addition, Gardoni and collaborators have recently reported that reduced NR2B expression impairs LTP in Schaffer collaterals without the participation of NR2A [56]. Thus, the specific overexpression of NR2B, together with KAR 1 and KAR2 in Prmp - / - may participate in the enhanced seizures observed in the pyramidal layer of CA3 in Prnp - /mice. However, the NMDA receptor subunit NR2D is only present in the stratum oriens of the CA1 and CA2, the stratum lucidum of CA3 and the inner third of the molecular layer of the dentate gyrus [53]. Although we did not explore NR2D levels in the present study, it has recently been described that $\operatorname{PrP}^{\mathrm{c}}$ inhibits NR2D subunits [57], thus $\operatorname{PrP}^{\mathrm{c}}$-deficient neurons showed enhanced and drastically prolonged NMDA-evoked currents [57]. This may also explain our results, since the participation of NMDA receptor in KA-induced cell death in hippocampus has also been demonstrated in Prmp - / - neurons [35].

Recent reports have shown that $\operatorname{PrP}^{\mathrm{c}}$ decreases the extracellular levels of amyloid oligomers, which indicates that it might be a target for putative therapies in Alzheimer's disease [58]. However, our results show that a "gain of function" strategy to increase Prnp dosage in Alzheimer's disease or a "loss of function" in case of prionopathies to prevent $\operatorname{PrP}^{\mathrm{c}}$ to $\operatorname{PrP}^{\mathrm{sc}}$ conversion may impair natural function or $\operatorname{PrP}^{c}$ leading to devastating effects if natural expression levels are modified. In conclusion, we believe that present data should be taken into account in the development of future therapies.

\section{Materials and Methods}

\section{Mouse strains}

Prmp - /- mice bred from a C57BL6J/129, Ola/Sv background [5] were purchased from EMMA (Monterotondo, Italy) We backcrossed to C57BL/6J for at least 15 generations to obtain Prnp - / - and wild-type littermates. $22 \operatorname{Prn} p-/-$ adult mice were used in the study. In addition, 19 C57BL6J littermates were also used. $\operatorname{PrP}^{\mathrm{C}}$-overexpressing mice (Tg20 strain) were purchased from EMMA (Monterotondo). They were generated from Prmp - /mice as described by Fisher et al. [59]. $28 \mathrm{Tg} 20$ mice were used in this study. Experiments were carried out in accordance with the guidelines of the European Union (2003/65/CE) and current Spanish regulations (BOE 252/34367-91, 2005) for the use of laboratory animals in chronic studies. All experimental protocols were also approved by the respective local Ethical Committees.

\section{Mouse genotyping}

Specific primers for Prmp genotyping were designed in our laboratory based on the original $\mathrm{P} 10$ and $\mathrm{P} 3$ primers described elsewhere [5]: P10-new: 5'-cataatcagtggaacaagccc-3'; P4-new: 5'gctacaggtggataacccctc-3'; P3-new: 5'-gccttctatcgccttcttgac-3' .40 cycling condition were: $45^{\prime \prime} 95^{\circ} \mathrm{C}$; $45^{\prime \prime} 62^{\circ} \mathrm{C}$; $1^{\prime} 72^{\circ} \mathrm{C}$, followed by a final extension at $72^{\circ} \mathrm{C}$ for $5 \mathrm{~min}$. For $\mathrm{Tg} 20$ mice, the transgene was detected by specific primers as indicated [60].

\section{Kainate injections and scoring of seizure severity}

The C57BL6J strain is seizure resistant in comparison to other mouse genetic backgrounds [61,62]. As indicated, Prmp $-/-$ mice were generated on a C57BL6J/129, Ola/Sv background [5]. Nonlethal convulsive seizures were induced in wild-type mice by successive injections of kainate (KA) (Sigma, Saint Louis, Missouri, USA) dissolved in 0.1 M phosphate buffered saline (PBS) $\mathrm{Ph}=7.4$. Animals were weighed and injected i.p. with one pulse of KA ( $8 \mathrm{mg} / \mathrm{kg}$ b.w.) every $30 \mathrm{~min}$ for $2 \mathrm{~h}$ (making a total of four pulses). Injected animals displayed forelimb clonus, rearing and falling, or continuous tonic clonic seizures. They were observed for 4 hours after the first injection. Seizure intensity was evaluated as described elsewhere [63,64]. After the first KA injections, affected animals became hypoactive and immobile (Grade I-II). After successive injections, hyperactivity (Grade III) and scratching (Grade IV) were often observed. Some animals (especially Prnp - / - and Tg20 mice) progressed to a loss of balance control (Grade V) and further chronic whole-body convulsions (Grade VI). The behavior known as pop-corn bouncing was included in Grade VI of the scale used in our study. Multiple doses of KA treatments were used to identify the threshold of KA-mediate seizures.

Fluoro Jade-B staining of dying neurons in brain sections

Mice were perfused with phosphate buffered $4 \%$ paraformaldehyde, $\mathrm{pH}=7.3$, postfixed overnight in the same fixative, and cryoprotected in buffered 30\% sucrose. Coronal sections $(30-\mu \mathrm{m}$ thick) were obtained in a freezing microtome and processed in parallel. Free-floating sections were rinsed for 2 hours in Tris $0.1 \mathrm{M}, \mathrm{pH}=7.4$, mounted and air-dried at room temperature overnight. Next day, sections were pretreated for $3 \mathrm{~min}$ in absolute alcohol, followed by $1 \mathrm{~min}$ in $70 \%$ ethanol and $1 \mathrm{~min}$ in distilled water. They were then oxidized in a solution of $0.06 \% \mathrm{KMnO}_{4}$ for $15 \mathrm{~min}$. Following three rinses of $1 \mathrm{~min}$ each in distilled water, the sections were incubated for $30 \mathrm{~min}$ in a solution of $0.001 \%$ Fluoro Jade-B (Chemicon, Temecula, USA) containing $0.01 \%$ of DAPI in $0.1 \%$ acetic acid. The slides were then rinsed in deionised water for $3 \mathrm{~min}$ each, dried overnight, rinsed in xylene and coverslipped with Eukitt ${ }^{\text {TM }}$ (Merck, Germany). Sections were examined using an epifluorescent microscope with blue-violet excitation light set at $450 \mathrm{~nm}$ and $350 \mathrm{~nm}$, respectively. Fluoro-Jade stained cells emit green light with an excitation peak at $480 \mathrm{~nm}$ and an emission peak around $525 \mathrm{~nm}$.

\section{Electrophysiological experiments in behaving mice}

A total of 24 (8 from each experimental group) male adults (3-5 months old; 25-35 g) were used in the electrophysiological study. Additional animals were used in a preliminary study of the stability of the recording and stimulating systems. Upon arrival in the laboratory, animals were housed in separate cages ( $\mathrm{n}=8$ per cage), 
but they were switched to individual cages after surgery. Mice were kept on a $12 \mathrm{~h}$ light/dark cycle with constant ambient temperature $\left(22 \pm 1^{\circ} \mathrm{C}\right)$ and humidity $(55 \pm 8 \%)$. Food and water were available ad libitum.

\section{Surgery}

Animals were anesthetized with $0.8-3 \%$ halothane (AstraZeneca, Madrid, Spain). The gas mixture was delivered through a small anesthesia mask (David Kopf Instruments, Tujunga, CA) connected to a calibrated Fluotec 5 (Fluotec-Ohmeda, Tewksbury, MA, USA) vaporizer at a flow rate of $1-4 \mathrm{~L} / \mathrm{min}$ oxygen. Animals were implanted with bipolar stimulating electrodes in the right Schaffer collateral-commissural pathway of the dorsal hippocampus (2 $\mathrm{mm}$ lateral and $1.5 \mathrm{~mm}$ posterior to Bregma; depth from the brain surface, 1.0-1.5 $\mathrm{mm}$ [65]. A recording electrode was also implanted in the ipsilateral stratum radiatum underneath the CAl area $(1.2 \mathrm{~mm}$ lateral and $2.2 \mathrm{~mm}$ posterior to Bregma; depth from the brain surface, $1.0-1.5 \mathrm{~mm})$. Electrodes were made of $50 \mu \mathrm{m}$, Teflon-coated tungsten wires (Advent Research Materials, Eynsham, UK), bared at their tips for $\approx 0.3 \mathrm{~mm}$. The recording electrode was implanted in the CAl area using as a guide the field potential depth profile evoked by paired $(40 \mathrm{~ms}$ interval) pulses presented to the ipsilateral Schaffer collateral pathway. The recording electrode was fixed at the site where a reliable monosynaptic ( $\leq 4 \mathrm{~ms}$ of latency) CA3-CA1 fEPSP was recorded. In short, the electrical stimulation of Schaffer collaterals evoked an afferent volley into the CAl area, usually appearing as a small triphasic (positive-negative-positive) potential, with a latency of $\approx 1.5-2 \mathrm{~ms} \pm 0.5 \mathrm{~ms}$ (Figure 2). The afferent volley was followed, $\approx 2 \mathrm{~ms}$ later, by a large negative wave when recorded at the stratum radiatum (see ref. [23] for details). A $0.1 \mathrm{~mm}$ bare silver wire was affixed to the skull as a ground. All the wires were connected to a four-pin socket (RS-Amidata, Madrid, Spain). The socket was affixed to the skull by two small screws and dental cement. Further details are provided elsewhere [23,24] Experimental sessions started one week after surgery.

\section{Electrophysiological recording procedures}

Recording sessions were carried out with 3 animals at a time. Animals were placed in separate small $(5 \times 5 \times 10 \mathrm{~cm})$ plastic chambers located inside a larger Faraday box $(30 \times 30 \times 20 \mathrm{~cm})$. Extracellular recordings were made with a high impedance probe $\left(2 \times 10^{12} \Omega, 10 \mathrm{pF}\right)$ using differential amplifiers with a bandwidth of $0.1 \mathrm{~Hz}-10 \mathrm{kHz}$ (P511, Grass-Telefactor, West Warwick, RI, USA). For input-output curves, the stimulus intensity of paired pulses presented to Schaffer collaterals was raised from $0.01 \mathrm{~mA}$ to $0.2 \mathrm{~mA}$ in steps of $10 \mu \mathrm{A}$ (Fig. 2). The selected stimulus interval was $40 \mathrm{~ms}$, because this interval presents maximum facilitation for the CA3-CAl synapse [24]. In all cases, the pair of pulses of a given intensity was repeated 5 times with time intervals $\geq 30 \mathrm{~s}$, to minimize interferences with slower short-term potentiation (augmentation) or depression processes [28]. To record pairedpulse facilitation at different $(10,20,40,100,200$, and $500 \mathrm{~ms})$ inter-stimulus intervals (Fig. 3), pulse intensity (50-400 $\mu \mathrm{A})$ was set at $30-40 \%$ of the amount necessary to evoke a maximum fEPSP response $[23,29]$. To evoke long term potentation (LTP), we used an HFS session consisting of five $200 \mathrm{~Hz}, 100 \mathrm{~ms}$ trains of pulses at a rate of $1 / \mathrm{s}$. This protocol was presented six times, at intervals of $1 \mathrm{~min}$. Field EPSP baseline values were collected $15 \mathrm{~min}$ prior to LTP induction using paired (40 ms inter-stimulus interval) $100 \mu \mathrm{s}$, square, biphasic pulses, presented every $20 \mathrm{~s}$. As indicated above, paired-pulse intensity for baseline recordings and after the HFS session was set at $30-40 \%$ of the amount necessary to evoke a maximum fEPSP response and at an inter-stimulus interval of
$40 \mathrm{~ms}$. In order to avoid evoking a population spike or unwanted EEG seizures, the stimulus intensity during the HFS train was that used to generate baseline records. After each HFS session, the same paired-pulse stimuli ( $40 \mathrm{~ms}$ inter-stimulus interval) were presented every $20 \mathrm{~s}$ for $30 \mathrm{~min}$ during the first LTP session and for $15 \mathrm{~min}$ on the following two days.

\section{Drug administration in electrophysiology procedures}

$\mathrm{KA}$ was dissolved in $0.1 \mathrm{M}$ phosphate buffered saline (PBS) at $\mathrm{pH}$ 7.4. KA was injected at a dose of $8 \mathrm{mg} / \mathrm{kg}$, i.p., $30 \mathrm{~min}$ before input/output curves and the paired-pulse test.

\section{Electrode location in electrophysiological procedures}

At the end of the experiments, mice were deeply re-anesthetized (sodium pentobarbital, $50 \mathrm{mg} / \mathrm{kg}$ ), and perfused transcardially with saline and $4 \%$ phosphate-buffered paraformaldehyde (PFA). Selected brain sections $(50 \mu \mathrm{m})$ including the dorsal hippocampus were obtained on a microtome (Leica, Wetzlar, Germany), mounted on gelatinized glass slides and Nissl stained with $0.1 \%$ Toluidine blue to determine the location of stimulating and recording electrodes.

\section{Analysis of the electrophysiological data}

Field EPSPs and 1-volt rectangular pulses corresponding to stimulus presentations were stored digitally on a computer through an analog/digital converter (CED 1401 Plus, Cambridge, England), at a sampling frequency of $11-22 \mathrm{kHz}$ and an amplitude resolution of 12 bits. Commercial computer programs (Spike 2 and SIGAVG from CED) were modified to represent EMG and fEPSP recordings. Data were analyzed off-line for quantification of CRs and fEPSP slope with the help of home-made representation programs [23]. Computed data were processed for statistical analysis using the SPSS for Windows package. Unless otherwise indicated, data are reported as the mean \pm SEM. Acquired data were analyzed using a two-way ANOVA test, with group, session, or time as repeated measure. Contrast analysis was added to further study significant differences.

\section{Expression profiling analysis of WT, Prnp -/- and Tg20 with Illumina ${ }^{\mathrm{TM}}$ bead arrays}

To determine gene expression changes in the three mouse strains, we performed a global transcriptome analysis using Illumina Sentrix 6 mouse v2 bead arrays. Total RNA from 4 mice (biological replicate experiments of wild-type, $\operatorname{Prn} p-/-$ and Tg20) was extracted from hippocampi and genotype. RNA concentration was measured with a Nanodrop ${ }^{\text {TM }}$, and RNA quality was assessed by Bioanalyzer ${ }^{\text {TM }}$ with RIN (RNA integrity number) ranging between 8.5 and 10.0. For each sample, $200 \mathrm{ng}$ of total RNA was reverse transcribed, amplified by in vitro transcription and labeled with biotin-UTP using the Illumina Total Prep RNA amplification kit (IL1791, Applied Biosystem/ Ambion, Austin, TX, USA) following the manufacturer's instructions. Labeled sample quality was assessed by Nanodrop ${ }^{\mathrm{TM}}$ and Bioanalyzer $^{\mathrm{TM}}$. After pre-heating to $65^{\circ} \mathrm{C}$ for $5 \mathrm{~min} 750 \mathrm{ng}$ of biotinylated cRNA was hybridized in a BeadChip Hyb Chamber with rocking for $16 \mathrm{~h}$ at $58^{\circ} \mathrm{C}$. On the following day, bead arrays were washed in Illumina ${ }^{\mathrm{TM}}$ washing solutions in a Hybex waterbath: first with static incubation for $10 \mathrm{~min}$ at $55^{\circ} \mathrm{C}$ in E1BC solution, followed by 10 rinses by dipping in the same solution and shaking $5 \mathrm{~min}$ at 90 r.p.m. in an orbital shaker; the next wash was by dipping 10 times in 100\% ethanol and shaking $10 \mathrm{~min}$ at 110 r.p.m. in an orbital shaker; this was followed by another wash in E1BC solution, dipping ten times, followed by 
2 min shaking at 90 r.p.m. Washed bead arrays were blocked in E1 buffer for $10 \mathrm{~min}$ in a rocking incubator and for a further $10 \mathrm{~min}$ with $2 \mathrm{ml}$ of $\mathrm{E} 1$ buffer plus streptavidin-Cy3. The fluorescent reagent was removed with E1BC solution, dipping ten times, plus 5 min shaking at 140 r.p.m. Finally, bead arrays were dried by centrifugation for 4 min at 275 r.p.m., followed by scanning in the Illumina Beadstation. The Beadscan software generates *.tif images and extracts raw data as tabulated text files. The raw data were summarized per probe using BeadStudio software Gene Expression and the summary data file was processed using the PILLA Web interface tool (Lozano et al, unpublished) an implementation of the Lumi package [66] developed within the Bioconductor project in the $\mathrm{R}$ statistical programming environment [67]. Data were normalized using the RSN (robust spline normalization) method and the VST (variancestabilizing transformation) method. The $\log 2$ intensities were media centered and $\log$ ratios were computed as differences in $\log 2$ intensities for each probe. The SAM (significance analysis of microarrays) two-class unpaired comparison test was applied with 100 permutations to detect significant differences in gene expression between treated and control conditions, initially setting the statistical significance at a false discovery rate of $5 \%$, with an arbitrary absolute fold chance cutoff set at 1.2 [68]. Whole genome expressional data results were filtered, with criteria selection of 1.2 Fold Change and Q-value less than 5\%.

\section{Microarray functional analysis}

We used the Ingenuity Pathway Analysis (IPA) software. Annotation of expression data was performed with reference to a number of sources which include; NIH DAVID the Gene Ontology Consortium, Kyoto Encyclopedia of Genes and Genomes (KEGG) pathway [http://david.abcc.ncifcrf.gov, http://www.geneontology.org, http://www.genome.jp/kegg/ pathway.html]. The IPA tool was used to identify the biological functions that were most significant to the data set. Canonical pathways were also identified from the IPA library; canonical pathways that were most significant to the data set were selected [69]. The significance of the association between the data set and the canonical pathway was measured in 2 ways: i) a ratio of the number of genes from the data set that map to the pathway divided by the total number of genes that map to the canonical pathway was calculated. ii) Fischer's exact test was used to calculate a $p$-value determining the probability that the association between dataset genes and the canonical pathway is significant.

\section{RT-qPCR}

RT-qPCR was carried out using ABI PRISM 7700 sequence detection system equipment and power Sybr Green master mix (Applied Biosystems). Reaction volumes of $12.5 \mu \mathrm{l}$ were used with $0.5 \mu \mathrm{M}$ primers. Specific primers were taken from a database (http://pga.mgh.harvard.edu/primerbank/) based on the published sequences (see Table S1). Amplification conditions consisted of $2^{\prime \prime}$ denaturation at $95^{\circ} \mathrm{C} ; 15^{\prime \prime}$ of annealing at $60^{\circ} \mathrm{C}$; and $1 \mathrm{~min}$ elongation at $60^{\circ} \mathrm{C}$ for 40 cycles. The results were normalized by the expression levels of the housekeeping gene, gapdh, which was quantified simultaneously with the target gene. To this mixture, we added $1 \mu \mathrm{l}$ of the serially diluted cDNA prepared from tissue. A melting point analysis was carried out to improve the sensitivity and specificity of amplification reactions detected with the Sybr Green I dye. Data were analyzed by SDS 1.9.1 Software (Applied Biosystems) following the $2^{-\Delta \Delta \mathrm{CT}}$ method [70]. The significance of differences was assessed using the Student's $t$-test and the Sigma Stat software.

\section{Supporting Information}

Figure S1 Photomicrographs of the CAl region showing the pattern of GFAP immunostaining in untreated Tg20 mice (A) and after KA treatment $(\mathrm{B}-\mathrm{C})$. GFAP immunoreactivity strongly increased in the CAl of KA-treated $\mathrm{Tg} 20$ mice. In addition, GFAP-positive cells after KA-treatment displayed the classical morphology of reactive cells with tick cellular expansions (arrows in $\mathrm{C}$ ). Abbreviations as in Fig. 1. Scale bars $\mathrm{A}=100 \mathrm{um}$ pertains to B. $\mathrm{C}=50$ um.

Found at: doi:10.1371/journal.pone.0007592.s001 (5.21 MB TIF)

Figure S2 A diagram illustrating the experimental design of the electrophysiological experiments carried out in behaving mice. (A) Animals were implanted with bipolar stimulating electrodes (St.) oriented towards the right Schaffer collateral-commissural pathway of the dorsal hippocampus and with a recording (Rec.) electrode aimed at the ipsilateral stratum radiatum underneath the CAl area. A bare silver wire was affixed to the skull as a ground. (B-C) Photomicrographs illustrating the location of stimulating (B) and recording $(\mathrm{C})$ electrodes. Scale bars are $200 \mu \mathrm{m}$. Abbreviations: D, L, M, V, dorsal, lateral, medial, ventral; DG, dentate gyrus; Sub., subiculum.

Found at: doi:10.1371/journal.pone.0007592.s002 (3.51 MB TIF)

Figure S3 Venn diagrams $(\mathrm{A}-\mathrm{C})$ and histogram (D) representing the functional microarray analysis between Tg20, Prnp - / - and wild-type mice using IPA software. In A-C the number of regulated $(\mathrm{A})$; the down-regulated $(\mathrm{B})$ and the up-regulated $(\mathrm{C})$ genes as well as the genes shared between genotypes are shown. (D) Histogram illustrating the canonical pathways ( $\mathrm{X}$ axis) including co-regulated genes with higher probability (indicated by the threshold (dashed line) of the $-\log (\mathrm{p}$-value)). Squares and connecting lines between bars indicate the gene number tendency between functions.

Found at: doi:10.1371/journal.pone.0007592.s003 (1.14 MB DOC)

Table S1 List of PCR primers used in the RT-qPGR validation. Found at: doi:10.1371/journal.pone.0007592.s004 (0.04 MB DOG)

\section{Acknowledgments}

We thank María Esteban and Isabel M. Jimenez for her technical assistance and Roger Churchill and Robin Rycroft for their editorial help.

\section{Author Contributions}

Conceived and designed the experiments: AGiM RG JMT JMDG JADR. Performed the experiments: AR NM AGiM RG FL JMT. Analyzed the data: AR NM AGiM RG FL LS JMT JADR. Contributed reagents/ materials/analysis tools: LS JMDG. Wrote the paper: JMDG JADR.

\section{References}

1. Borchelt DR, Scott M, Taraboulos A, Stahl N, Prusiner SB (1990) Scrapie and cellular prion proteins differ in their kinetics of synthesis and topology in cultured cells. J Cell Biol 110: 743-752.

2. Prusiner SB (1986) Prions are novel infectious pathogens causing scrapie and Creutzfeldt-Jakob disease. Bioessays 5: 281-286.

3. Prusiner SB, DeArmond SJ (1994) Prion diseases and neurodegeneration. Annu Rev Neurosci 17: 311-339.

4. Pan KM, Baldwin M, Nguyen J, Gasset M, Serban A, et al. (1993) Conversion of alpha-helices into beta-sheets features in the formation of the scrapie prion proteins. Proc Natl Acad Sci U S A 90: 10962-10966. 
5. Bueler H, Fischer M, Lang Y, Bluethmann H, Lipp HP, et al. (1992) Normal development and behaviour of mice lacking the neuronal cell-surface PrP protein. Nature 356: 577-582.

6. Aguzzi A, Baumann F, Bremer J (2008) The prion's elusive reason for being. Annu Rev Neurosci 31: 439-477.

7. Linden R, Martins VR, Prado MA, Cammarota M, Izquierdo I, et al. (2008) Physiology of the prion protein. Physiol Rev 88: 673-728.

8. Carleton A, Tremblay P, Vincent JD, Lledo PM (2001) Dose-dependent, prion protein $(\mathrm{PrP})$-mediated facilitation of excitatory synaptic transmission in the mouse hippocampus. Pflugers Arch 442: 223-229.

9. Colling SB, Collinge J, Jefferys JG (1996) Hippocampal slices from prion protein null mice: disrupted $\mathrm{Ca}(2+)$-activated K+ currents. Neurosci Lett 209: 49-52.

10. Collinge J, Whittington MA, Sidle KC, Smith CJ, Palmer MS, et al. (1994) Prion protein is necessary for normal synaptic function. Nature 370: 295-297.

11. Mallucci GR, Ratte S, Asante EA, Linehan J, Gowland I, et al. (2002) Post-natal knockout of prion protein alters hippocampal CA1 properties, but does not result in neurodegeneration. Embo J 21: 202-210.

12. Lledo PM, Tremblay P, DeArmond SJ, Prusiner SB, Nicoll RA (1996) Mice deficient for prion protein exhibit normal neuronal excitability and synaptic transmission in the hippocampus. Proc Natl Acad Sci U S A 93: 2403-2407.

13. Maglio LE, Perez MF, Martins VR, Brentani RR, Ramirez OA (2004) Hippocampal synaptic plasticity in mice devoid of cellular prion protein. Brain Res Mol Brain Res 131: 58-64.

14. Maglio LE, Martins VR, Izquierdo I, Ramirez OA (2006) Role of cellular prion protein on LTP expression in aged mice. Brain Res 1097: 11-18.

15. Herms JW, Kretzchmar HA, Titz S, Keller BU (1995) Patch-clamp analysis of synaptic transmission to cerebellar purkinje cells of prion protein knockout mice. Eur J Neurosci 7: 2508-2512.

16. Curtis J, Errington M, Bliss T, Voss K, MacLeod N (2003) Age-dependent loss of PTP and LTP in the hippocampus of PrP-null mice. Neurobiol Dis 13: 55-62.

17. Le Pichon CE, Valley MT, Polymenidou M, Chesler AT, Sagdullaev BT, et al. (2009) Olfactory behavior and physiology are disrupted in prion protein knockout mice. Nat Neurosci 12: 60-69.

18. Tobler I, Gaus SE, Deboer T, Achermann P, Fischer M, et al. (1996) Altered circadian activity rhythms and sleep in mice devoid of prion protein. Nature 380: 639-642.

19. Criado JR, Sanchez-Alavez M, Conti B, Giacchino JL, Wills DN, et al. (2005) Mice devoid of prion protein have cognitive deficits that are rescued by reconstitution of PrP in neurons. Neurobiol Dis 19: 255-265.

20. Coitinho AS, Roesler R, Martins VR, Brentani RR, Izquierdo I (2003) Cellular prion protein ablation impairs behavior as a function of age. Neuroreport 14: 1375-1379.

21. Coitinho AS, Freitas AR, Lopes MH, Hajj GN, Roesler R, et al. (2006) The interaction between prion protein and laminin modulates memory consolidation. Eur J Neurosci 24: 3255-3264.

22. Coitinho AS, Lopes MH, Hajj GN, Rossato JI, Freitas AR, et al. (2007) Shortterm memory formation and long-term memory consolidation are enhanced by cellular prion association to stress-inducible protein 1. Neurobiol Dis 26: 282-290.

23. Gruart A, Munoz MD, Delgado-Garcia JM (2006) Involvement of the CA3CAl synapse in the acquisition of associative learning in behaving mice. J Neurosci 26: 1077-1087.

24. Madronal N, Delgado-Garcia JM, Gruart A (2007) Differential effects of longterm potentiation evoked at the CA3 CA1 synapse before, during, and after the acquisition of classical eyeblink conditioning in behaving mice. J Neurosci 27: 12139-12146.

25. Schwartzkroin PA (1986) Hippocampal slices in experimental and human epilepsy. Adv Neurol 44: 991-1010.

26. Madronal N, Gruart A, Delgado-Garcia JM (2009) Differing presynaptic contributions to LTP and associative learning in behaving mice. Front Behav Neurosci 3: 7 .

27. Turrigiano GG, Nelson SB (2004) Homeostatic plasticity in the developing nervous system. Nat Rev Neurosci 5: 97-107.

28. Zucker RS, Regehr WG (2002) Short-term synaptic plasticity. Annu Rev Physiol 64: 355-405.

29. Gureviciene I, Ikonen S, Gurevicius K, Sarkaki A, van Groen T, et al. (2004) Normal induction but accelerated decay of LTP in APP+PS1 transgenic mice. Neurobiol Dis 15: 188-195.

30. Volianskis A, Jensen MS (2003) Transient and sustained types of long-term potentiation in the CA1 area of the rat hippocampus. J Physiol 550: 459-492.

31. Sokolov MV, Rossokhin AV, Behnisch T, Reymann KG, Voronin LL (1998) Interaction between paired-pulse facilitation and long-term potentiation of minimal excitatory postsynaptic potentials in rat hippocampal slices: a patchclamp study. Neuroscience 85: 1-13.

32. Lauri SE, Palmer M, Segerstrale M, Vesikansa A, Taira T, et al. (2007) Presynaptic mechanisms involved in the expression of STP and LTP at CA1 synapses in the hippocampus. Neuropharmacology 52: 1-11.

33. Roucou X, Gains M, LeBlanc AC (2004) Neuroprotective functions of prion protein. J Neurosci Res 75: 153-161.

34. Sakudo A, Onodera T, Suganuma Y, Kobayashi T, Saeki K, et al. (2006) Recent advances in clarifying prion protein functions using knockout mice and derived cell lines. Mini Rev Med Chem 6: 589-601.

35. Rangel A, Burgaya F, Gavin R, Soriano E, Aguzzi A, et al. (2007) Enhanced susceptibility of Prnp-deficient mice to kainate-induced seizures, neuronal apoptosis, and death: Role of AMPA/kainate receptors. J Neurosci Res 85: 2741-2755.

36. Walz R, Amaral OB, Rockenbach IC, Roesler R, Izquierdo I, et al. (1999) Increased sensitivity to seizures in mice lacking cellular prion protein. Epilepsia 40: 1679-1682.

37. Chiarini LB, Freitas AR, Zanata SM, Brentani RR, Martins VR, et al. (2002) Cellular prion protein transduces neuroprotective signals. Embo J 21: 3317-3326.

38. McLennan NF, Brennan PM, McNeill A, Davies I, Fotheringham A, et al. (2004) Prion protein accumulation and neuroprotection in hypoxic brain damage. Am J Pathol 165: 227-235.

39. Nicolas O, Gavin R, Braun N, Urena JM, Fontana X, et al. (2007) Bcl-2 overexpression delays caspase-3 activation and rescues cerebellar degeneration in prion-deficient mice that overexpress amino-terminally truncated prion. Faseb J 21: 3107-3117.

40. Huang S, Liang J, Zheng M, Li X, Wang M, et al. (2007) Inducible overexpression of wild-type prion protein in the muscles leads to a primary myopathy in transgenic mice. Proc Natl Acad Sci U S A 104: 6800-6805.

41. Chiesa R, Piccardo P, Biasini E, Ghetti B, Harris DA (2008) Aggregated, wildtype prion protein causes neurological dysfunction and synaptic abnormalities. J Neurosci 28: 13258-13267.

42. Westaway D, DeArmond SJ, Cayetano-Canlas J, Groth D, Foster D. Degeneration of skeletal muscle, peripheral nerves, and the central nervous system in transgenic mice overexpressing wild-type prion proteins. 1994. p. 117.

43. Mouillet-Richard S, Ermonval M, Chebassier C, Laplanche JL, Lehmann S, et al. (2000) Signal transduction through prion protein. Science 289: 1925-1928.

44. Schneider B, Mutel V, Pietri M, Ermonval M, Mouillet-Richard S, et al. (2003) NADPH oxidase and extracellular regulated kinases $1 / 2$ are targets of prion protein signaling in neuronal and nonneuronal cells. Proc Natl Acad Sci U S A 100: 13326-13331.

45. Powell AD, Toescu EC, Collinge J, Jefferys JG (2008) Alterations in Ca2+buffering in prion-null mice: association with reduced afterhyperpolarizations in CA1 hippocampal neurons. J Neurosci 28: 3877-3886.

46. Whatley SA, Powell JF, Politopoulou G, Campbell IC, Brammer MJ, et al. (1995) Regulation of intracellular free calcium levels by the cellular prion protein. Neuroreport 6: 2333-2337.

47. Ferreiro E, Resende R, Costa R, Oliveira CR, Pereira CM (2006) An endoplasmic-reticulum-specific apoptotic pathway is involved in prion and amyloid-beta peptides neurotoxicity. Neurobiol Dis 23: 669-678.

48. Iihara K, Joo DT, Henderson J, Sattler R, Taverna FA, et al. (2001) The influence of glutamate receptor 2 expression on excitotoxicity in Glur2 null mutant mice. J Neurosci 21: 2224-2239.

49. Telfeian AE, Federoff HJ, Leone P, During MJ, Williamson A (2000) Overexpression of GluR6 in rat hippocampus produces seizures and spontaneous nonsynaptic bursting in vitro. Neurobiol Dis 7: 362-374.

50. Macdonald RL, Gallagher MJ, Feng HJ, Kang J (2004) GABA(A) receptor epilepsy mutations. Biochem Pharmacol 68: 1497-1506.

51. Khosravani H, Zhang Y, Tsutsui S, Hameed S, Altier C, et al. (2008) Prion protein attenuates excitotoxicity by inhibiting NMDA receptors. J Gen Physiol 131: i5.

52. Yang EJ, Harris AZ, Pettit DL (2006) Variable kainate receptor distributions of oriens interneurons. J Neurophysiol 96: 1683-1689.

53. Thompson CL, Drewery DL, Atkins HD, Stephenson FA, Chazot PL (2002) Immunohistochemical localization of N-methyl-D-aspartate receptor subunits in the adult murine hippocampal formation: evidence for a unique role of the NR2D subunit. Brain Res Mol Brain Res 102: 55-61.

54. Janssen WG, Vissavajjhala P, Andrews G, Moran T, Hof PR, et al. (2005) Cellular and synaptic distribution of NR2A and NR2B in macaque monkey and rat hippocampus as visualized with subunit-specific monoclonal antibodies. Exp Neurol 191 Suppl 1: S28-44.

55. Fukushima F, Nakao K, Shinoe T, Fukaya M, Muramatsu S, et al. (2009) Ablation of NMDA receptors enhances the excitability of hippocampal CA3 neurons. PLoS ONE 4: e3993.

56. Gardoni F, Mauceri D, Malinverno M, Polli F, Costa C, et al. (2009) Decreased NR2B subunit synaptic levels cause impaired long-term potentiation but not long-term depression. J Neurosci 29: 669-677.

57. Khosravani H, Zhang Y, Tsutsui S, Hameed S, Altier C, et al. (2008) Prion protein attenuates excitotoxicity by inhibiting NMDA receptors. J Cell Biol 181: 551-565.

58. Lauren J, Gimbel DA, Nygaard HB, Gilbert JW, Strittmatter SM (2009) Cellular prion protein mediates impairment of synaptic plasticity by amyloid-beta oligomers. Nature 457: 1128-1132.

59. Fischer M, Rulicke T, Raeber A, Sailer A, Moser M, et al. (1996) Prion protein $(\mathrm{PrP})$ with amino-proximal deletions restoring susceptibility of $\operatorname{PrP}$ knockout mice to scrapie. Embo J 15: 1255-1264.

60. Steele AD, Emsley JG, Ozdinler PH, Lindquist S, Macklis JD (2006) Prion protein $(\mathrm{PrPc})$ positively regulates neural precursor proliferation during developmental and adult mammalian neurogenesis. Proc Natl Acad Sci U S A 103: 3416-3421

61. McKhann GM, 2nd, Wenzel HJ, Robbins CA, Sosunov AA, Schwartzkroin PA (2003) Mouse strain differences in kainic acid sensitivity, seizure behavior, mortality, and hippocampal pathology. Neuroscience 122: 551-561. 
62. McLin JP, Steward O (2006) Comparison of seizure phenotype and neurodegeneration induced by systemic kainic acid in inbred, outbred, and hybrid mouse strains. Eur J Neurosci 24: 2191-2202.

63. Peng YG, Clayton EC, Means LW, Ramsdell JS (1997) Repeated independent exposures to domoic acid do not enhance symptomatic toxicity in outbred or seizure-sensitive inbred mice. Fundam Appl Toxicol 40: 63-67.

64. Lee JY, Cole TB, Palmiter RD, Koh JY (2000) Accumulation of zinc in degenerating hippocampal neurons of ZnT3-null mice after seizures: evidence against synaptic vesicle origin. J Neurosci 20: RC79.

65. Paxinos G, Franklin KBJ, Franklin KBJ, The mouse brain in stereotaxic coordinates. 2nd ed. 2001, San Diego: Academic Press. xxv, [264] p.

66. Du P, Kibbe WA, Lin SM (2008) lumi: a pipeline for processing Illumina microarray. Bioinformatics 24: 1547-1548.
67. Gentleman RC, Carey VJ, Bates DM, Bolstad B, Dettling M, et al. (2004) Bioconductor: open software development for computational biology and bioinformatics. Genome Biol 5: R80.

68. Tusher VG, Tibshirani R, Chu G (2001) Significance analysis of microarrays applied to the ionizing radiation response. Proc Natl Acad Sci U S A 98: 5116-5121.

69. Sorensen G, Medina S, Parchaliuk D, Phillipson C, Robertson C, et al. (2008) Comprehensive transcriptional profiling of prion infection in mouse models reveals networks of responsive genes. BMC Genomics 9: 114 .

70. Livak KJ, Schmittgen TD (2001) Analysis of relative gene expression data using real-time quantitative PCR and the 2(-Delta Delta C(T)) Method. Methods 25: 402-408. 